\title{
Enhanced Residential Bathroom Sustainability: Challenges and Opportunities
}

\author{
VishnudasChettiappilly Hari ${ }^{* 1}$, Maryam Imani ${ }^{* 2}$, Ahad Ramezanpour ${ }^{* 3}$ \\ 1,2,3 Mar317, Marconi Building, Anglia Ruskin University, Bishop Hall Lane, Chelmsford, UK, CM11SQ \\ *Corresponding author: ahad.ramezanpour@anglia.ac.uk
}

\begin{abstract}
The research reviews the rationale behind water and energy saving in the domestic application within the bathroom unit in the UK. Various technologies for water saving including rainwater harvesting and greywater recycling and the related regulatory issues are reviewed. Various water saving toilets, as well as waste water heat recovery systems, were discussed and compared. The incentives, impact, challenges, and opportunities for various stakeholders including end user, property developers, technology companies and researchers, utility companies and the government are analysed. The review shows that greywater recycling for toilet flushing has highest user acceptance and is inevitable for zero/close to zero carbon home development. It was found that technology barriers are still an important factor in the application of the current products, including adaptability and size to fit a wide range of bathrooms as well as initial cost. The retrofitability of any technology was found important to create a timely impact on the decline of resources and infrastructure stress. The article gathers a range of technological and market challenges based on the individual components and technologies in the bathroom and concludes that an integrated approach is required for an effective technology in the bathroom.
\end{abstract}

Keywords: bathroom; domestic building; energy recovery; smart cities;water saving; sustainability

\section{INTRODUCTION}

The water industry collects, treats and supplies more than 16 billion litres of water every day for domestic and commercial customers in the UK. Of this, about 6 billion tonnes are put into the public water supply. Electricity generation uses 9 billion tonnes, industry 2.1 billion, farming 0.2 billion, and other uses, such as fish farming, account for the rest (Defra, 2008). According to Future UK climate projections, annual average precipitation across the UK may decrease slightly, by between 0 and $15 \%$ by the 2080s (Defra, 2008). This is quite alarming to know that the UK has less available water per person than most other European countries (Eurostat Water Statistics - Planned article, 2015). This is even more stressful in the South east of England as the most water stressed region (Environment Agency, 2013).Ofwat (2007) reported that nearly 52\% of all public water supply is used at the household level. Household water and energy demands have been increasing since the 1950s, due to population growth and changes, household formation and development and lifestyles leading to increased pressure on water supply and resources system. Household water use, the single largest component of mains water use, is the focus of many water efficiency initiatives, particularly in the more densely populated and water-stressed areas of the UK. In the UK, the average person consumes approximately 150 lit/day of potable water for personal uses (Defra, 2008). UK government has a target of reducing water consumption by $20 \%$ per person by 2030 (Department for Communities and Local Government, 2010). Defra (2008), has discussed this vision through cost effective measures, and reduced consumption to an average of 130 litres per person per day by 2030, or possibly even 120 litres per person per day depending on new technological developments and innovation.

Total energy consumption in the UK is already six times what it was in 1950 (WWDR), and is projected to grow by as much as $55 \%$ by 2030 as the combined effect of population growth and the improvement of living standards (UN, water and energy sustainability). The energy used in homes accounts for more than a quarter of energy use and carbon dioxide emissions in the United Kingdom and heating energy is by far the biggest slice of UK household energy use (Defra, 2013). EU Energy Efficiency Directive (2012) has set the target to reduce primary energy consumption by $20 \%$ by 2020 against business as usual projections through building renovation, Combined Heat and Power Plant and National Energy Efficiency Action Plan. In line with this, Defra (2012) has set the target of 196TWh energy saving in 2020, equivalent to 22 power stations, through socially cost-effective investment. That is around $11 \%$ lower than the business as a usual baseline (i.e. 1990). It could also reduce carbon emissions by $41 \mathrm{MtCO} 2 \mathrm{e}$, contributing to achieving the carbon budgets.

The growing development and demands along with climate changes such as cold and prolonged winters haveput an upward pressure on GHG emissions. Added to this, significant changes in heating systems, comfort expectations, insulation and use of appliances have transformed carbon emissions from housing. The UK 
government Carbon Plan (2011) has set the target to cut GHG emissions by $80 \%$ by 2050 and this will need dramatic 'energy efficiency' and 'water efficiency' across all sectors. For example, for the energy sector, this sets out four possible scenarios for 2050, relative to 1990, which implies a per capita demand reduction of between $31 \%$ and $54 \%$ relative to 2007 .

There are many hidden impacts of excessive water and energy consumption and their combined effect, in a business as usual scenario, might have outstanding effects on the environment and will put at risk maintaining the economic and social advances (UN - Water and Energy sustainability, 2014). Waterwise has outlined four major impacts that will cause environmental, social and financialchallenges. More water abstraction that degrades natural water resources, degradation of surface water due to polluted surface runoff flushing into them; and also, costly upgrade and maintenance of water supply and wastewater treatment infrastructure.

Water and energy tariffs and price and affordability consumers have been always discussed. In 2015-16, the average combined bills for water companies ranged from $£ 329$ (Severn Trent Water) to £532 (South West Water) (Ofwat, 2015). According to Ofwat(2015) - Department for Work and Pension's Family Resources Survey (2013-14), has found that 24\% of households in England and Wales spend more than 3\% of their income on water and sewerage bills and $11 \%$ spend more than $5 \%$.Also, the average annual electricity bill for all households monitored in the Household Electricity Survey (2010-11) was around $£ 530$ (at 2012 prices). This was $10 \%$ higher than the UK national average, costing on average an extra $£ 50$.

Considering the fact that over $62 \%$ of water usage and over $60 \%$ of the energy used to heat water in domestic sector takes place in the bathroom area, this research investigates the challenges and opportunities of saving water and energy in the bathroom. The water saving is important not only due to water scarcity, the decline in recourses, and increase in demand, but also due to the fact that embedded energy in every one litre of the water supplied in the household is $3.186 \mathrm{KJ}$ and equivalent to $0.4 \mathrm{~g}$ of CO2 emissions (Energy saving trust, 2013).

\section{A. Bathroom Unit}

A standard bathroom unit contains a toilet and its connected cistern, a shower and/or bath, and a basin (see Fig 1). Bathroom unit operation demands cold water and hot water supply. According to Energy Saving Trust (2013), bathroom and shower, together, have the largest proportion of waterconsumption (i.e. 33\%) in a house and with $22 \%$ water consumption for toilet flushing and $7 \%$ hot tap water demand, the totalof $62 \%$ water consumptionin the bathroom unit is obtained.

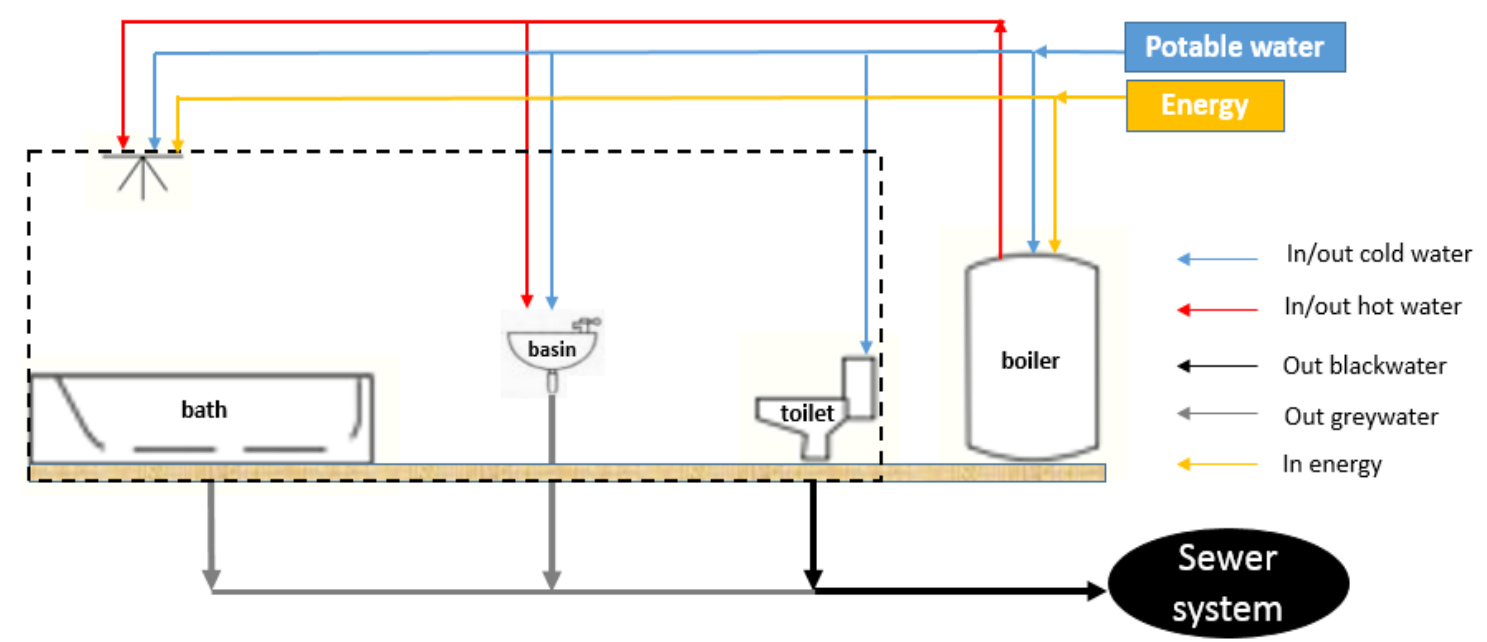

Fig 1. A schematic of a standard bathroom unit

\section{B. Bathroom unit demands}

Fig. 1 shows a schematic of a standard bathroom unit appliances and their operational connections. Potable cold water is used at showerhead in different types of showers (e.g. gravity-feed, electric, combi and so on showers). This cold water is mixed with the hot water to adjust the water temperature toa user-desired degree $\left(40^{\circ} \mathrm{C}-43{ }^{\circ} \mathrm{C}\right)$. Basin is one of the frequent users of potable cold water in a bathroom. Traditional UK basinshave separate cold and hot water taps. Mixed taps have been introduced to the UK homes, that mix cold and hot water inside the tap and the outflow temperature is adjusted by the user to a desirable degree. The toilet is one of the main consumers of the water in a house. Conventional toilets consume potable cold water for flushing purpose. Currently, a wide range of bathroom unit products (shower, bath, toilet and basin) are available in the market. These products have different prices with different specifications and different level of operational efficiencies.Hot water is used for showering, bath and basin tap uses in a bathroom unit. Conventionally, boilers are used to heat up the inflow cold water and storethe hot water required for the 
bathroomand other household uses. This hot water is maintained in a large tank and supplied when/where needed. There are several challenges with boilers such as its size and weight, fouling, corrosion and costly maintenance.Energy demand in a bathroom is related to the hot water supply (apart from the lighting) for basin and shower uses.Electricity is used to heat up the input cold water to a higher temperature (normally $60^{\circ} \mathrm{C}$ $\left.65^{\circ} \mathrm{C}\right)$.

Fig.2 shows a schematic of the inputs to a bathroom unit and the outputs as a result of itsoperation. Inputs are potable water and energy and outputs are greywater (from basin and shower/bath), blackwater (from the toilet) and indirect GHG emission due to water and energy consumption.

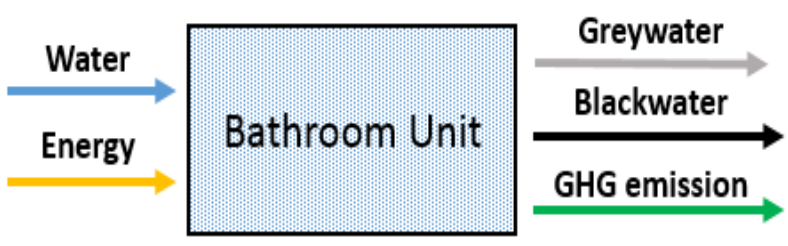

Fig 2 - schematic of a bathroom unit inputs and outputs

There have been always arguments about the efficiency of a bathroom unit appliances and their operation. Several water and energy saving products and technologies have been introduced to the market in order to reduce water and energy consumption, GHG emission and black/greywater production. These products/technologies can be categorised as follows:

1) Greywater reuse/recycling:Greywater reuse/recycling aims to save water consumption by reusing the water. Greywater reuse/recyclingtechnologies in a bathroom unit use the water from bathroom/shower and basin for toilet flushing. This resolves the issues around drinking water consumption for toilet flushing. Aside from the benefits of saving water (and on water bill), greywater reuse reduces the pressure on sewage treatment systems. Additionally, it will have ecological benefits such as reduced freshwater extraction from rivers and aquifers, reduced energy use and chemical pollution from treatment and greater quality of surface and ground water.

2) The heat recovery:Heat recovery process aims to improve energy efficiency by collection and re-using of heat arising from any process that would otherwise be lost. Products and technologies are currently available that are used in a bathroom unit to capture the heat from greywater (from showering and basin uses). In heat recovery process, the incoming cold water flows first through a heat exchanger where it is pre-warmed by heat from greywater flowing down from showering or washing in the basin. For example, the suitable water temperature for the human body, on average, is around $40 \mathrm{oC}$. During showeringprocess between $5 \mathrm{oC}-10 \mathrm{oCof}$ the water temperature is lost.There are various types of heat recovery productsavailable that can recover up to $75 \%$ of the remained heat from greywater (Słyś and Kordana, 2013). This process in addition to saving energy and energy bill will also indirectly contribute to carbon footprint reduction.

3) Toilet flushing:Using drinking water for toilet flushing is one of the most argued areas for water saving in a house. Waterwise in the UK has reported that about $16 \%$ of toilets still use 13 litres per flush, compared to $11 \%$ using the latest low-flush models with 6 litres (full) and 4 litres (short) flushes.An average household with a nine-litre toilet flushes around 110 litres down the pan (Environment Agency, 2007). Therefore, in addition to water saving technologies such as greywater reuse, there are products available that have improved a traditional toilet design in order to use less water for flushing such as dual flush toilets, Orrington high-efficiency toilet and so on.

Environment Protection Agency in Ireland (2013) has compared severalappliances in a house against various criteria such as water saving, energy saving, payback period, maintainability, user-friendliness, aesthetic design, maintenance cost and so on. Table 1 outlines a summary of these technologies in a bathroom unit.

TABLE 1. Water saving technologies in a bathroom unit

\begin{tabular}{|l|l|}
\hline \multicolumn{1}{|c|}{ Appliance } & Average Water Saving \\
\hline Dual flush toilet 2L (short flush) - 6L (long flush) & $16.3 \%$ \\
\hline High-efficiency pressure asset toilet (4 L - 4.8 L) & $13 \%$ \\
\hline Composting toilets & No water \\
\hline $\begin{array}{l}\text { Vacuum toilet (0.6 - 1L); Air assisted flush toilet } \\
\text { (e.g. propelair technology)- }\end{array}$ & $25 \%$ \\
\hline Waterless toilet & No water \\
\hline Low-flow shower heads (8.5L/min, 7 min shower) & $12 \%$ \\
\hline Tap aerator (spary-wide full) & $4.0-10 \%$ \\
\hline
\end{tabular}




\section{CURRENT TECHNOLOGIES}

Waterwise (2012) states that "Water efficiency is about reducing the amount of water wasted on a daily basis and not restricting its usage". The concept of water savings may be divided to direct and indirect water savings. Direct water savings intend to save water before its usage, on the other hand, indirect water saving accounts for used water/Greywater recycling. However, both concepts have same aim to reduce fresh water consumption.

\section{A. Direct Water Saving}

There are many direct methods, tips, and appliances available to save water at domestic level. Some of those methods/tips publishedby Waterwise (2017) such as stopping drips, dual flushing toilets, and so on. However, these methods do have their own limitations and boundaries and may demand changes to consumer's lifestyle.

1) Toilet flushing technologies:There are many toilet flushing technologies currently available in the market. Effective parameters for comparison of these technologies will include - cost, the volume of water used per flush, pan clearance and drainage system. For example, the split button function in a dual flush toilet gives the user the choice of how much water to be used. Dual flush toilets typically use 4-6 litres of water per flush when compared to 10-13 litres old style flush system. A dual flush toilet can be installed with siphon mechanism or push button flush valve mechanism.

Envirowise (2009) further compares Siphon mechanism, push button flush valve mechanism, variable flush, dual flush (siphon mechanism), dual flush (push button flush valve mechanism) and interruptible flush on the basis of advantages and disadvantages. Further analysis concludes that siphon mechanism is more effective, cheaper to retrofit and have less chance of leakage. Push button mechanism has disadvantages of being not robust as siphon due to the possibility of valve leakage and higher maintenance. It is thus concluded from Envirowise (2009) that a dual flush siphon mechanism with 2 flush volumes and interruptible flush siphon mechanism is a best available choice in the market to save water.

Table 2 shows a comparison among different toilet flushing technologies. Propelair's ultra-lowhighperformance toilet flushing show advantage compare to the current state of the art in all four parameters - cost, water used per flushing, pan clearance and drainage.

TABLE 2. Comparison of toilet flushing technologies

\begin{tabular}{|c|c|c|c|c|}
\hline Toilet Type & Cost (£) & Water/Flush (litres) & Pan Clearance & Drainage \\
\hline Standard & $315-772$ & 6 & Average & Standard \\
\hline Dual Flush & $315-772$ & $6 / 3$ & Average & Standard \\
\hline Low Flush & $315-772$ & $3.5 / 2$ & Poor $\sim 94 \%$ & Standard \\
\hline Macerating & 517 & 6 & Average & Standard + small bore \\
\hline Vacuum & 950 & $<1.5$ & Good & Non-standard drainage \\
\hline Compressed air & 850 & $<1.5$ & Poor to Average & Non-standard drainage \\
\hline Composting & $1500-5800$ & 0 & Poor & Non-standard drainage \\
\hline Propelair & $380 \sim 550$ & 1.5 & Excellent over $99 \%$ & Standard + small bore \\
\hline
\end{tabular}

Fig. 3 shows other types of standalone products (meaning that there isn't a solution that can integrate different bathroom products to save water and energy) available in the UK market.

2) Detecting leaks within toilet:According to Johnson and Burton (2010), 20\% of the total supply and 234 million litres a day more than a decade ago are lost through leaking pipes and toilets in England and Wales. A small leak in a toilet will directly add to high water consumption where this scenario can be avoided by detecting leaks. The water lost would meet the daily needs of 21.5 million people.

Propelair innovative water and energy saving toilets use $84 \%$ less water ( 1.5 litres per flush) in comparison to the UK average 9 litres or higher due to double flushing, leakages and valve issues. Considering that approximately one-litre water is required to seal the pan after waste discharge and half a litre is required for cleaning the pan, Propelair technology uses minimum possible water among technologies that do not completely change user experience when a toilet is used (Vacuum, Composting, etc). Propelair also promises to reduce leakages through a siphon system for a leak proof operation however it requires electrical supply that uses approximately one kilo joules per flush (considering embedded energy in water, the product is still saving up to $80 \%$ energy). The Propelair toilets require the user to close the lid before the flush and the domestic version of the product is still under development. Table 3 illustrates carbon foot print comparison of conventional, modern and the Propelair toilet technologies. 


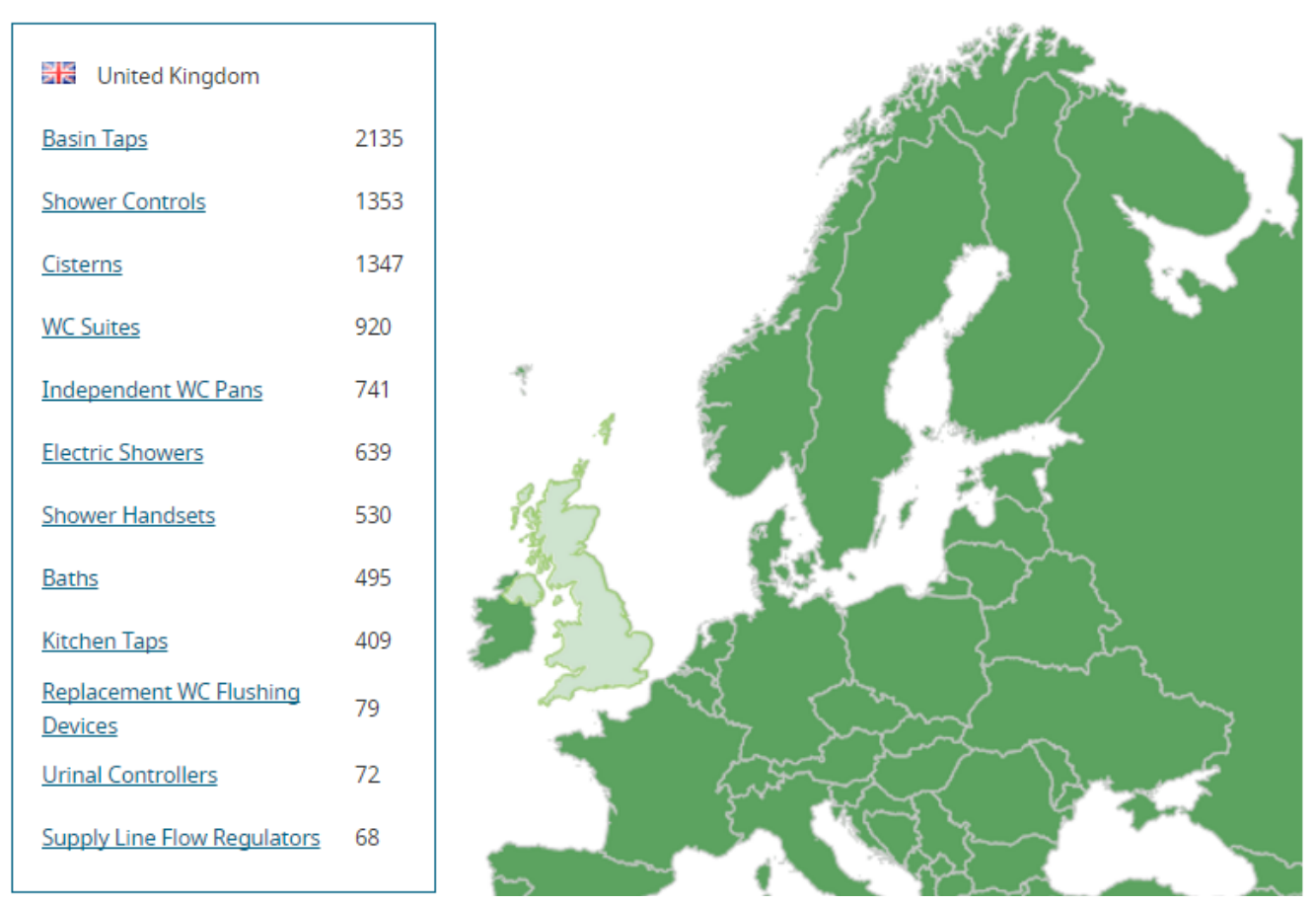

Fig3: Types of standalone products for direct water saving in the UK (Water label, 2017)

TABLE 3. Energy saving: Propelair vs Conventional WC/ Mordern WC

\begin{tabular}{|l|l|l|l|}
\hline \multicolumn{1}{|c|}{ Description } & \multicolumn{1}{c|}{ Conventional WC } & \multicolumn{1}{c|}{ Modern WC } & Propelair WC \\
\hline $\begin{array}{l}\text { WC flush volumes } \\
\text { (litres) }\end{array}$ & $\begin{array}{l}9-12 \\
\text { southwestwater.co.uk, } \\
(2016) .\end{array}$ & $\begin{array}{l}\text { 5-7 Grant, N. and Moodie, } \\
\text { M. (1999), (Home-water- } \\
\text { works.org, 2017) }\end{array}$ & $\begin{array}{l}1.5 \text { (Propelair, } \\
2017)\end{array}$ \\
\hline $\begin{array}{l}\text { Embedded energy per } \\
\text { litre (Joules) }\end{array}$ & 3186 & & 3186 \\
\hline Energy per flush (Joules) & 0 & & 1000 \\
\hline Total energy used & 28674 & & 5779 \\
\hline Carbon (co2 g) & $5.31-7.08$ & $2.95-4.13$ & 0.885 \\
\hline
\end{tabular}

Propelair can connect to existing drains using a $2 \mathrm{inch} / 50 \mathrm{~mm}$ flexible waste pipe, which the air flush can push the waste through without a gradient, unlike conventional toilets which rely on a fall in the plumbing network (Propelair, 2017). One of the challenges for the Propelair toilet commercialisation is the possible vulnerability of the sewage system to blockage considering only 1.5-litre flush volume both within the building and local drain system however it can be argued that the drain system designed and worked for many years when overall water usage was dramatically lower than current times. The company recently awarded a research fund through Horizon 2020 for a comprehensive swage monitoring when the Propelair toilets installed within a local sewage zone.

\section{B. Indirect Water Saving}

An indirect water recycling system utilises used and recycled water for some selected purposes. Rain water harvesting system andgreywater recycling system are namely major contributors. Greywater is the term used when addressing all waste water produced within a household, apart from toilet wastewater or black water. Sullage, grey/waste water, and light waste water are also other terms in use. Greywater is wasted water from showers, bath, hand basins, washing machines, dishwashers, laundries and kitchen sinks (Morel and Diener, 2006). Unlike rain water recycling system, which completely depends on rainfall (Seasonal), greywater recycling system can supply plentiful on a daily basis. Therefore, the fresher water used within a household the more greywater available to recycle (Ferguson, 2014).

1) Rain water harvesting:Rain water is a result of the natural distillation process and only risk from airborne particles and from man-made pollution. In the areas of regular rainfall, best available way to save water indirectly is a collection of rain water called 'rainwater harvesting' (Wateraid, 2013). According to (Parkes et al., 2011), a rain water system will need to collect, store and transport stored water to points of use. It is further assumed that buildings have a water mains backup system for uninterrupted supply. According to BS 8515 (2009) regulations, rainwater can be categorised into three basic types; Direct Feed systems, Header Tank 
systems, and Gravity systems. The categorisation is based on the location of rainwater storage and accordingly mechanism of supplying water.

2) Rain water harvesting system suitability: It's important to make sure that an RWH system is suitable for a specific need. The factors need to be considered before deciding whether an RWH system is appropriate, are potential water collection, storage capabilities, cost, and considerations of alternative water efficiency measures.

It is possible to work out the amount of rainwater that can be collected by calculating the amount of rain that falls in particular region and whether sufficient collection area is available to meet required demand.Fig.4 illustrates a typical Direct Feed RWH (Shreeve, Ward and Butler, 2013).

UK has fairly regular rainfall spread during the year, meaning unused space in storage tanks is reduced, making UK rainwater harvesting projects even more ideal. Table 4 summarises some common uses of rain water harvesting projects and its treatments (Envirowise, 2008). It is also seen that for toilet flushing purposes, quality of water required is low and is achieved using coarse filters.

The main disadvantage of RWH is its installation costs, which is variable due to many factors like storage tank location, tank capacity, the involvement of pump and continuous replacement of filters. Average of $£ 2,000$ to $£ 3,000$ is the cost that a quality RWH system recommended by UK Rainwater Management Association. Commonly ground tanks are installed for water storage where excavation is possible. Occasionally, excavation and installation of underground storage tank can be disruptive and may need to re-route some service to accommodate the process.

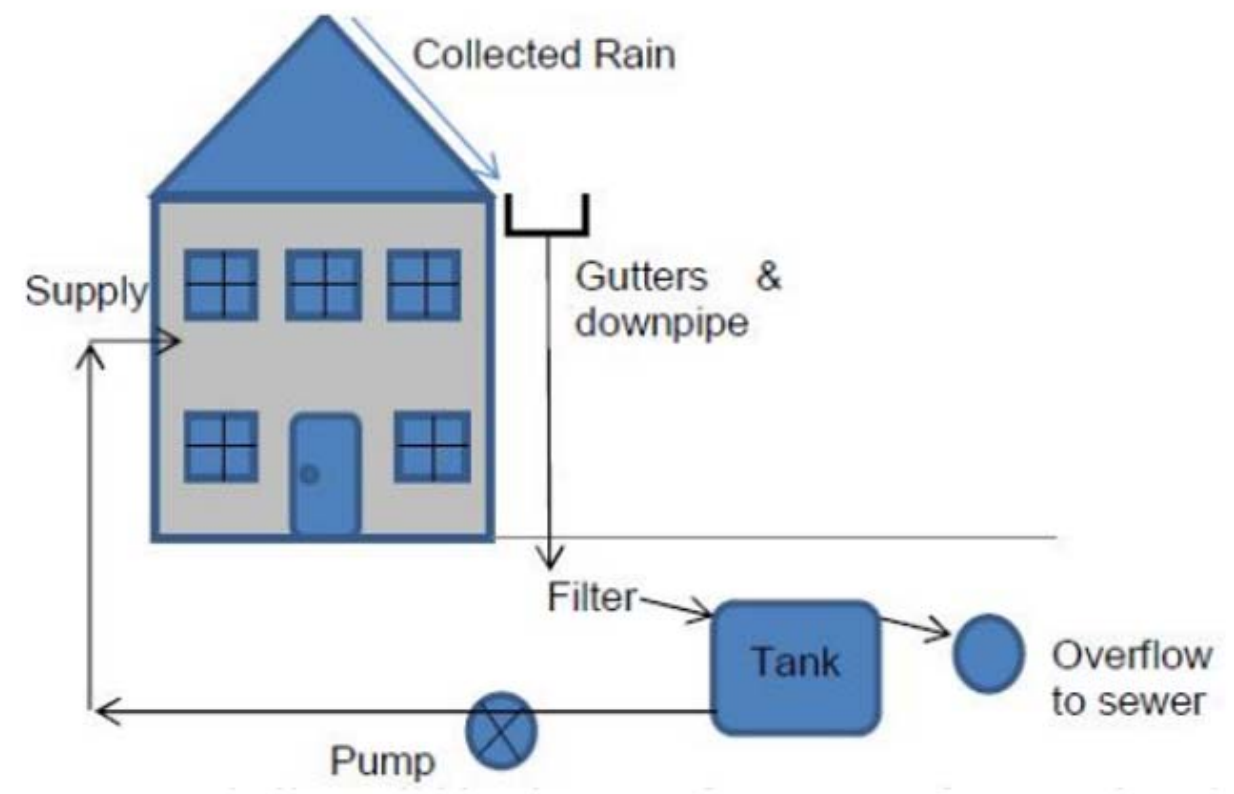

Fig4: Schematic view of basic rain water harvesting in dwelling (Shreeve, Ward and Butler, 2013)

TABLE 4. Common uses of RWH systems and required water quality (Envirowise, 2008)

\begin{tabular}{|c|c|c|}
\hline Water use & Quality required & Treatment options \\
\hline $\begin{array}{l}\text { Nurseries, sports ground, gardens } \\
\text { Toilet flushing } \\
\text { Cooling (Boilers) } \\
\text { General cleaning } \\
\text { Filter Backwashing }\end{array}$ & $\begin{array}{l}\text { Low: Water is not used for } \\
\text { consumption and there is very low } \\
\text { risk of contact. Water should look } \\
\text { clean and be odour free. }\end{array}$ & $\begin{array}{l}\text { Frist flush diverted } \\
\text { Coarse filter }\end{array}$ \\
\hline $\begin{array}{l}\text { Laundry } \\
\text { Cleaning of equipment or process } \\
\text { cleaning }\end{array}$ & $\begin{array}{l}\text { Medium: Water is not used for } \\
\text { consumption, and there is low risk } \\
\text { of contact. Water must be clean } \\
\text { and odour free, but not necessarily } \\
\text { sterile }\end{array}$ & $\begin{array}{l}\text { All of the above, plus } \\
\text { Fine filter (possibly membrane } \\
\text { filter) }\end{array}$ \\
\hline $\begin{array}{l}\text { Food processing } \\
\text { Cleaning food processing } \\
\text { equipment } \\
\text { Substitute potable supply }\end{array}$ & $\begin{array}{l}\text { High: Water may be used for } \\
\text { consumption, water must be clean, } \\
\text { odour free and sterile }\end{array}$ & $\begin{array}{l}\text { All of the above, plus } \\
\text { Pathogen removal and/or } \\
\text { inactivation (eg UV treatment) }\end{array}$ \\
\hline
\end{tabular}




\section{Domestic greywatercategories}

Greywater can be classified according to its origin and characteristics. As far as origin/source is concerned greywater can be differentiated from bathroom, laundry, and kitchen(Morel, 2005). Fig. 5 shows a typical centralised greywater recycling in a domestic application. The system includes a backup potable water feed for thefail-safe operation of the package (Lowenergyhouse.com, 2017). According to FBR (n.d), greywater from showers, bathtubs, and hand wash basins are low load and greywater from the kitchen (dish washers), washing machines are considered to be a high load. Also adds that greywater from bathtubs, showers and hand basin are considered to be a least polluted source of greywater. Fig. 5 illustrates a typical indirect water saving through the use of greywater recycling in a typical dwelling. Table 5 shows types of greywater and their characteristics from microbiological, biological, physical and chemical aspects in a household application.

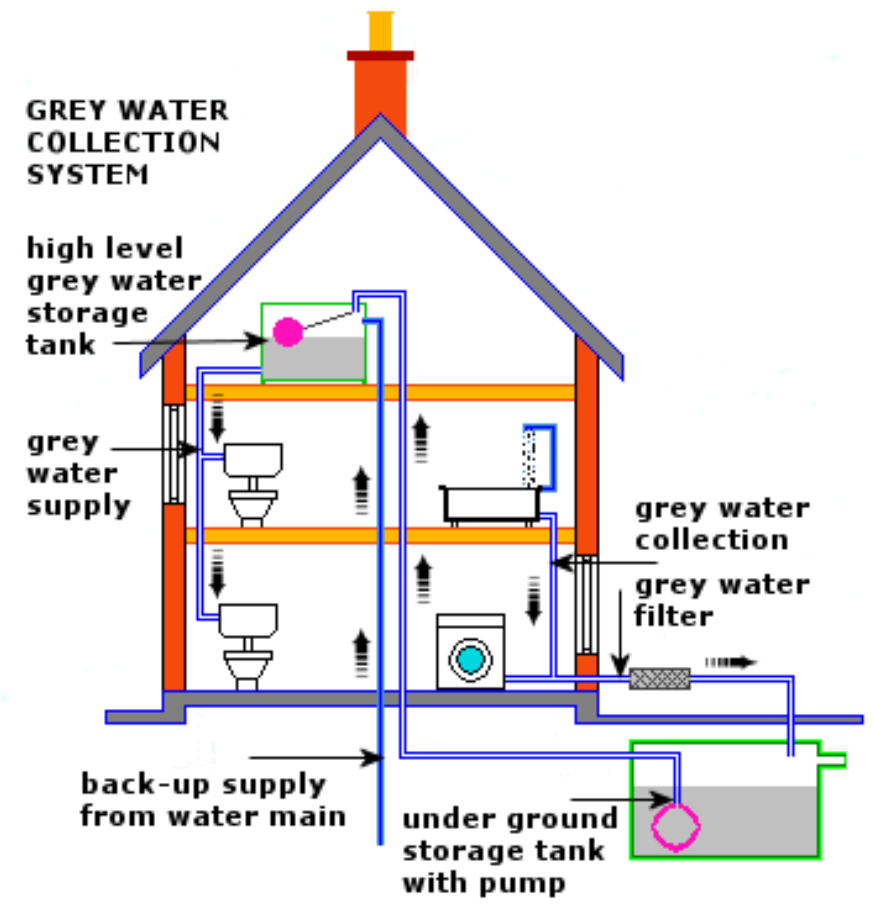

Fig 5: A typical greywater recycling system in dwellings (Lowenergyhouse.com, 2017)

TABLE 5. Summary of the composition of untreated greywater according to the source (Morel, 2005).

\begin{tabular}{|l|l|}
\hline Waste water source & Characteristics \\
\hline Bathroom & $\begin{array}{l}\text { Microbiological: lower levels of thermotolerant coliforms } \\
\text { Chemical: soap, shampoo, hair dyes, toothpaste, body fats, oils and } \\
\text { cleaning chemicals } \\
\text { Physical: high in suspended solids, hair, turbidity and cleaning } \\
\text { products. } \\
\text { Biological: lower levels of concentrations of biochemical oxygen } \\
\text { demand }\end{array}$ \\
\hline Laundry & $\begin{array}{l}\text { Microbiological: variable thermotolerant coliform loads } \\
\text { Chemical: sodium, phosphate, boron, surfactants, ammonia and } \\
\text { nitrogen from soap powders and soiled clothes } \\
\text { Physical: high in suspended solids, lint and turbidity } \\
\text { Biological: high in biochemical oxygen demand (BOD) }\end{array}$ \\
\hline Kitchen & $\begin{array}{l}\text { Microbiological: variable thermotolerant coliform loads } \\
\text { Chemical: detergents, cleaning agents } \\
\text { Physical: food particles, oils, fats, grease, turbidity } \\
\text { Biological: high in biochemical oxygen demand }\end{array}$ \\
\hline
\end{tabular}




\section{Greywater recycling regulations}

According to Environment Agency (2011),Greywater from showers, baths and wash basins are contaminated with human intestinal bacteria as well as virus and other organic debris namely skin particles and hair. Bathroom greywater may also contain residues of body cleaning products, cosmetic products, body fat that often constitute of nutrients for bacterial growth. The combination of bacteria, organic material and relatively high temperature from heated greywater can encourage bacterial growth. Therefore, it is recommended not to store untreated greywater for a prolonged time. Environment Agency (2011), also states that most significant risk is from pathogenic microorganism present in greywater which is derived from faecal contamination, although physical and chemical agents present in this water promote the growth of bacteria. For these reasons, water quality of greywater must be physical, chemically and biologically suitable for its intended reuse. There are currently no regulations that cover the quality of recycling water, however, British Standard Institute (BSI) has produced guidelines for domestic reuse of greywater. The four microbiological water quality indicators that considered are Escherichia coli, Enterococci, Legionella, and Total coliforms. The guidelines for monitoring the bacteriological health risk of greywater for various application provided by the Environment Agency (2011). The guidelines indicate that if the monitoring values are higher than 10 times the specified guideline, use of greywater must be suspended however the values below the guideline illustrates system under control. Furthermore, any value in between requires resampling to confirm results.

British Standards BS8525-1:2010 Greywater Systems Code of Practice

Greywater reuse can be quite safe for public health when managed properly. Two primary ways of managing risk are:

1) treating greywater before reusing it

2) eliminating physical contact with the greywater(CSBE, 2003).

\section{E. Storage of Greywater}

Storage of greywater is not a preferable scenario. Greywater must be filtered and treated before it is transferred to a storage tank, however, it can only be stored for a limited period of time. According to NSW Government (2008), storage of untreated greywater is strictly not recommended as all forms of wastewater storage will turn septic unless treated appropriately.Greywater storage when turn septic will give rise to positive conditions for rapid multiplication of micro- organisms and offensive odours. It is found that during the first 24- 48 hours of greywater storage, Thermotolerant coliforms have been multiplied by 10 to 100 times its initial population, before gradually declining. Analysis of stored greywater for eight days' time showed a significant level of pathogens, however, it is unlikely for pathogens to multiply and grow in greywater at a low infective dose (number of organisms that need to cause disease), some group of pathogenic micro- organisms are still of concern. In conclusion, it is advised to avoid greywater storage other than in a temporary surge tank unless treated adequately.

\section{F. Greywater treatment systems and technology selection}

Any design of greywater system that involves storage of greywater must be treated adequately prior to storage as micro-organisms and bacteria can multiply. Disinfection and filtration are primary methods used by physical and chemical greywater treatment systems while biological treatment includes the process of aeration and membrane bioreactors to remove contaminants. A list of available greywater treatment technologies, including their advantage and disadvantages, are listed in table 6. It is evident from the characterisation of greywater which reveals that it needs to treated to a high standard before its reused, in order to avoid or eliminate health risk, environmental effects and negative aesthetic. One of the major aim of greywater recovery and reuses is to remove organic content, suspended solids and micro-organisms due to its positive relationship with negative aesthetic and health characteristics. Standalone, coarse and soil filtration methods are incapable of reducing physical, chemical and micro- biological parameter to require values stated by non-potable reuse guidelines. Excellent removal of suspended solids, turbidity and pathogens can be achieved by micro filtration and ultrafiltrationmembrane;however, it provides limited removal of dissolved organic matter (Fig. 6) (Li, Wichmann and Otterpohl, 2009).

The MBR is the only technology that is able to achieve efficient and satisfactory removal of organic substances, microbial contaminations and surfactants without disinfection or post filtration step. According to Pidou (2006), standard and qualities of the MBR effluent technology meet most non-potable urban greywater reuse standards. While RBC biological technology can even recycle black greywater, the system can only be practically and economically feasible when installing to seven-storey building having approximately 28 flats (Friedler and Hadari, 2006). This technology further is installed to all flats where centralised water recycling takes place. Public acceptance of using recycled greywater for toilet flushing is of concern. The most economical and feasible solution to greywater recycling is the combination of the aerobic biological process with disinfection or physical filtration. However, the disadvantage would include constant replacement of physical filter and products required for disinfection. Coagulation and ion exchange followed by membrane filtration offer 
chemical solution treatment for low strength greywater to achieve requirements of unrestricted non-potable urban reuses (Li, Wichmann and Otterpohl, 2009).

According to Nolde (2005), biological systems in combination with physical treatment provides the most efficient system for greywater treatment. This technology combination has proved to reduce the BOD of greywater to below $10 \mathrm{mg}$ providing satisfactory effluent quality than systems only apply physical processes. For past 20 years, biological systems have been successfully employed for treatment of greywater.

TABLE 6. Greywater treatment categories, characteristics, advantages and disadvantages

\begin{tabular}{|c|c|c|c|}
\hline Treatment Technique & Description & Advantages & Disadvantages \\
\hline $\begin{array}{l}\text { Chemical treatment of } \\
\text { GW } \\
\text { Disinfection } \\
\text { Activated carbon filter } \\
\text { coagulation and } \\
\text { flocculation, } \\
\text { electrocoagulation, } \\
\text { adsorption using } \\
\text { granular activated } \\
\text { carbon (GAC) and } \\
\text { natural zeolites, } \\
\text { magnetic ion exchange } \\
\text { resin (MIEX), powdered } \\
\text { activated carbon (PAC) } \\
\text { Advanced oxidation } \\
\text { processes (AOPs) such } \\
\text { as ozonation, and photo } \\
\text { catalysis } \\
\text { (Li, Wichman and } \\
\text { Otterpohl 2009; Boyjoo, } \\
\text { Pareek and Ang, 2013) }\end{array}$ & $\begin{array}{l}\text { Chlorine, ozone, or } \\
\text { ultraviolet light can all be } \\
\text { used to disinfect greywater. } \\
\text { Activated carbon has been } \\
\text { treated with oxygen to open } \\
\text { up millions of tiny pores } \\
\text { between the carbon atoms. } \\
\text { This results in highly } \\
\text { porous surfaces with areas } \\
\text { of } 300-2,000 \text { square meters } \\
\text { per gram. These filters thus } \\
\text { are widely used to adsorb } \\
\text { odorous or coloured } \\
\text { substances from gases or } \\
\text { liquids. } \\
\text { Chemical processes such as } \\
\text { coagulation, followed by a } \\
\text { filtration and/or disinfection } \\
\text { stage, can reduce the } \\
\text { suspended solids, organic } \\
\text { substances, and surfactants } \\
\text { in low-strength greywater } \\
\text { to an acceptable level that } \\
\text { can meet non-potable urban } \\
\text { reuse needs (Lin et al., } \\
\text { 2005; Pidou et al., 2008). }\end{array}$ & $\begin{array}{l}\text { Highly effective in } \\
\text { killing bacteria if } \\
\text { properly designed and } \\
\text { operated, low operator } \\
\text { skill requirement. } \\
\text { Simple operation, } \\
\text { activated carbon is } \\
\text { particularly good at } \\
\text { trapping organic } \\
\text { chemicals, as well as } \\
\text { inorganic compounds } \\
\text { like chlorine. } \\
\text { Chemical solutions } \\
\text { are especially } \\
\text { attractive for single } \\
\text { household low- } \\
\text { strength greywater } \\
\text { treatment systems, as } \\
\text { the variability in the } \\
\text { strength and flow of } \\
\text { the greywater did not } \\
\text { affect their treatment } \\
\text { performance (Pidou et } \\
\text { al., 2008) }\end{array}$ & $\begin{array}{l}\text { Chlorine and ozone can } \\
\text { create toxic by-products, } \\
\text { ozone and ultraviolet can } \\
\text { be adversely affected by } \\
\text { variations in the organic } \\
\text { content of greywater. } \\
\text { Needs to be manually } \\
\text { topped up increasing costs. } \\
\text { High capital cost, many } \\
\text { other chemicals are not } \\
\text { attracted to carbon at all } \\
\text {-- sodium, nitrates, etc. } \\
\text { This means that an } \\
\text { activated carbon filter will } \\
\text { only remove certain } \\
\text { impurities. } \\
\text { not sufficient to meet the } \\
\text { non-potable reuse } \\
\text { standards, especially for } \\
\text { high strength greywater } \\
\text { Once all of the bonding } \\
\text { sites are filled, an activated } \\
\text { carbon filter stops working } \\
\text { and requires replacement. }\end{array}$ \\
\hline $\begin{array}{l}\text { Physical treatment of } \\
\text { GW } \\
\text { (Physical treatment- } \\
\text { filtration and } \\
\text { sedimentation) } \\
\text { Screen meshes } \\
\text { sand bed filtration } \\
\text { nylon sock type filtration } \\
\text { metal strainers } \\
\text { gravel filtration } \\
\text { Mulch tower system } \\
\text { (Boyjoo, Pareek and } \\
\text { Ang, 2013) }\end{array}$ & $\begin{array}{l}\text { Beds of sand or in some } \\
\text { cases coarse bark or mulch } \\
\text { which trap and adsorb } \\
\text { contaminants as greywater } \\
\text { flows through. } \\
\text { The efficiency of the } \\
\text { filtration techniques } \\
\text { depends on the distribution } \\
\text { of greywater particle size } \\
\text { pollutants and the filters' } \\
\text { porosity; in general, the } \\
\text { smaller the filters' porosity } \\
\text { the better the effluent } \\
\text { quality. The pre-treatment } \\
\text { of raw greywater in storage } \\
\text { and settling tanks partially } \\
\text { mitigates the clogging } \\
\text { problems associated with } \\
\text { sand filters. }\end{array}$ & $\begin{array}{l}\text { Simple operation, low } \\
\text { maintenance, low } \\
\text { operation costs. } \\
\text { A mean removal of } \\
30 \% \text { COD and a } \\
\text { maximum E. coli } \\
\text { removal of two log } \\
\text { CFU/100 mL was } \\
\text { observed (Chaillou et } \\
\text { al. (2011) }\end{array}$ & $\begin{array}{l}\text { Solely using physical } \\
\text { greywater treatment } \\
\text { processes as the main } \\
\text { treatment method is } \\
\text { insufficient for greywater } \\
\text { treatment, since it does not } \\
\text { guarantee adequate } \\
\text { reduction of organics, } \\
\text { nutrients, and surfactants, } \\
\text { except in situations where } \\
\text { the organic strength is } \\
\text { extremely low (Ghaitidak } \\
\text { and Yadav, 2013). } \\
\text { Coarse filters have limited } \\
\text { effect on the removal of the } \\
\text { pollutants present in the } \\
\text { greywater (Li et al., 2009). } \\
\text { Filters face operational } \\
\text { problems such as cleaning } \\
\text { frequency (Ghaitidak and } \\
\text { Yadav, 2013) }\end{array}$ \\
\hline
\end{tabular}




\begin{tabular}{|c|c|c|c|}
\hline $\begin{array}{l}\text { Biological treatment of } \\
\text { GW } \\
\text { Aerobic biological } \\
\text { treatment } \\
\text { Or Active sludge } \\
\text { Rotating Biological } \\
\text { Contactor (RBC) } \\
\text { Sequencing Batch } \\
\text { Reactor (SBR), } \\
\text { Membrane Bioreactors } \\
\text { (MBR) } \\
\text { Fluidized Bed Reactor } \\
\text { (FBR) Upflow } \\
\text { Anaerobic Sludge } \\
\text { Blanket (UASB) }\end{array}$ & $\begin{array}{l}\text { Aerobic biological } \\
\text { treatment: Air is bubbled to } \\
\text { transfer oxygen from the air } \\
\text { into the greywater. Bacteria } \\
\text { present consume the } \\
\text { dissolved oxygen and digest } \\
\text { the organic contaminants, } \\
\text { reducing the concentration } \\
\text { of contaminants. } \\
\text { In active sludge treatment, } \\
\text { bacteria digest organic } \\
\text { material in the wastewater, } \\
\text { significantly reducing the } \\
\text { organic material, which is } \\
\text { measured as biological } \\
\text { oxygen demand (BOD) and } \\
\text { chemical oxygen demand } \\
\text { (COD). In the process, } \\
\text { nitrogen, phosphorus, } \\
\text { inorganic substances and } \\
\text { pathogens are also reduced. } \\
\text { Pathogen reduction is due } \\
\text { to competition, digestion } \\
\text { and sedimentation (World } \\
\text { Health Organization, } \\
\text { 2006)). } \\
\text { Uses aerobic biological } \\
\text { treatment and filtration } \\
\text { together to encourage } \\
\text { consumption of organic } \\
\text { contaminants and filtration } \\
\text { of all pathogens. } \\
\text { The MBR combines } \\
\text { biodegradation with } \\
\text { membrane filtration for } \\
\text { solid liquid separation. The } \\
\text { MBR has been regarded as } \\
\text { an innovative technology } \\
\text { for greywater treatment }\end{array}$ & $\begin{array}{l}\text { High degree of } \\
\text { operations flexibility } \\
\text { to accommodate } \\
\text { greywater of varying } \\
\text { qualities and } \\
\text { quantities, allows } \\
\text { treated water to be } \\
\text { stored. } \\
\text { It is the only } \\
\text { technology that can } \\
\text { achieve satisfactory } \\
\text { removal efficiencies } \\
\text { of organic substances, } \\
\text { surfactants, and } \\
\text { microbial } \\
\text { contaminations } \\
\text { without the need for } \\
\text { the post-filtration and } \\
\text { disinfection steps. } \\
\text { RBC and FBR were } \\
\text { found to be efficient at } \\
\text { treating light } \\
\text { greywater } \\
\text { The RBC requires } \\
\text { lower maintenance if } \\
\text { the number of stages } \\
\text { are increased. (Nolde, } \\
\text { 2000) }\end{array}$ & $\begin{array}{l}\text { High capital cost, high } \\
\text { operating cost, complex } \\
\text { operational requirements, } \\
\text { does not remove all } \\
\text { pathogens. } \\
\text { MBR-based greywater } \\
\text { treatment systems can be } \\
\text { economically realistic and } \\
\text { feasible when the building } \\
\text { size exceeds } 37 \text { stories ( } \\
\text { Friedler and Hadari, 2006). } \\
\text { Reasonable payback period } \\
\text { is still an unsolved problem } \\
\text { for single-household MBR } \\
\text { applications (Jabornig and } \\
\text { Podmirseg, 2015). }\end{array}$ \\
\hline
\end{tabular}




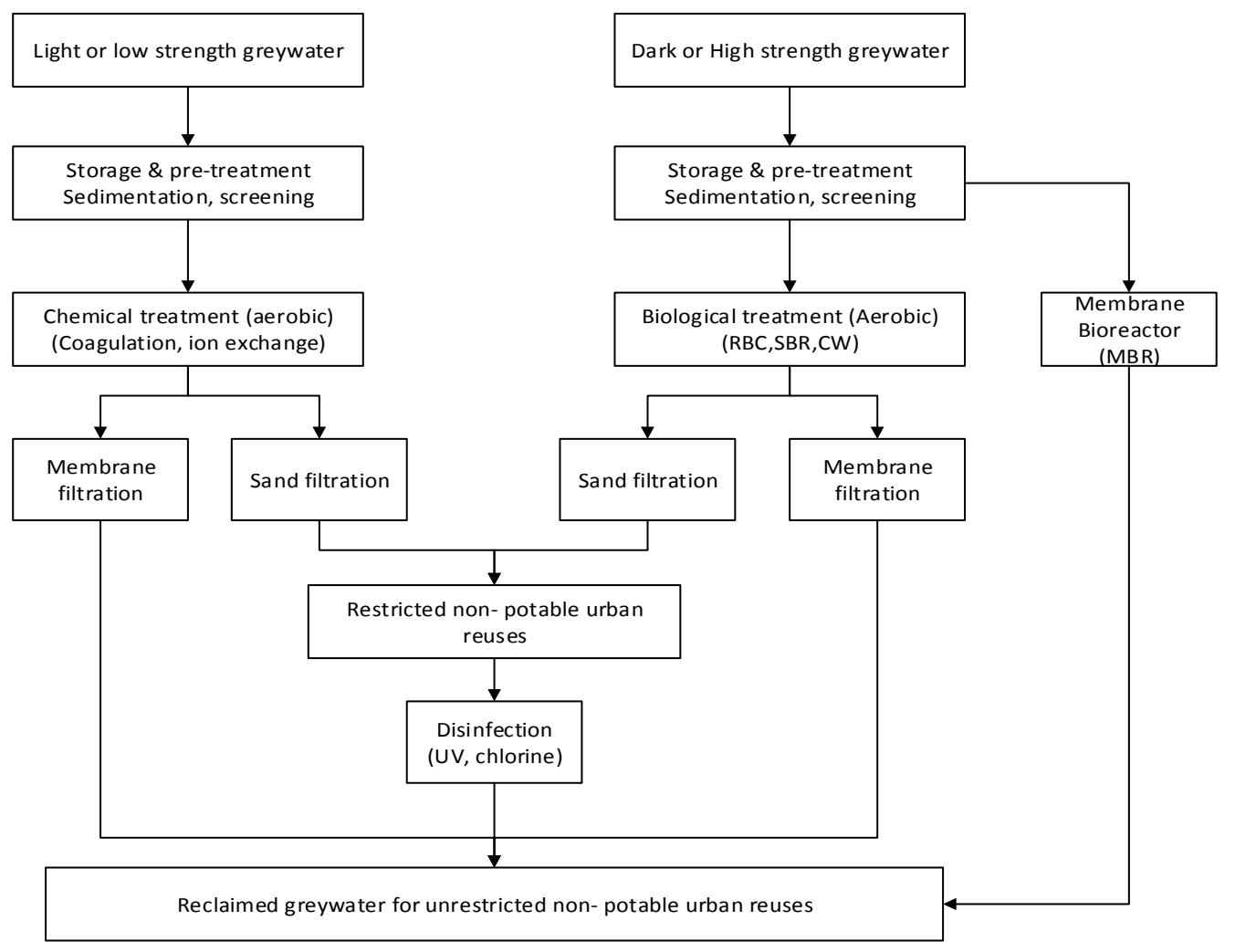

Fig 6: The greywater recycling schemes for non-potable urban reuses (Li, Wichmann and Otterpohl, 2009

It is observed that light greywater will undergo pre-treatment followed by temporary storage. Biological or chemical treatment together with membrane filtration offers efficient greywater recycling.

\section{G. Waste Water Heat Recovery (WWHR)}

Estimated around 8- to $90 \%$ of the energy used for heating water in homes ends up in the drain. After cooling and heating, the energy cost required to heat water is one of the biggest expense and most of that energy is being wasted by flowing down the drain. Harvesting or recovering heat from our showers is a way to save energy and money. Waste water heat recovery, domestic drain heat exchanger are not new concepts, however, it has not been implemented on small scale because of design and installation limitation and mostly been employed by large commercial applications (Markham, 2014).

An average of $875 \mathrm{~kg}$ of $\mathrm{CO} 2$ per household per year is emitted from energy used to heat water for devices and appliances in each household. This value is equivalent to the $\mathrm{CO} 2$ emissions caused by driving more than 1,700 miles in an average family car. The bathroom is the biggest consumer of hot water in the house and therefore it is this room responsible for the most water-related carbon emissions about $539 \mathrm{~kg}$ of CO2 (Energy saving trust, 2013).

Table 7 published by Energy saving trust (2013) shows that the showers are taken at an average temperature of $41 \mathrm{oC}$ followed by bathing at $44 \mathrm{oC}$. This table also shows the temperature rise required for each application which is critical to determine energy use and opportunities in energy saving.

TABLE 7. Temperature distribution table for various activities in bathroom (Energy saving trust, 2013)

\begin{tabular}{|l|l|l|}
\hline Water temperatures & Temperature (0C) & Temperature rise (0C) \\
\hline Mains & 13.4 & - \\
\hline Shower & 41.0 & 27.6 \\
\hline Basin Hot & 55.0 & 41.6 \\
\hline Kitchen Sink hot & 55.0 & 41.6 \\
\hline Bath & 44.0 & 30.6 \\
\hline \multicolumn{2}{|l|}{ Specific heat capacity $(\mathrm{kWh} / \mathrm{L} / \mathrm{K})$} & 0.00116 \\
\hline
\end{tabular}

During commercial waste heat recovery system, the waste water is routed separately to a plant room which runs across a heat exchanger and heat is extracted and stored in a thermal store. However, currently, this technology is not practically developed and applied in the most dwelling and domestic applications. Currently, the heat extracted from the waste water is required to be reused immediately. 
During a shower, as there is demand for hot water and further it runs to the drain the requirement for fresh hot water continues. A thermostatic shower is fed from both hot and cold water. If the cold water which is used by the shower has been pre-warmed, then less hot water is required to meet the design temperature. Used hot water exiting the shower will run to the main drain with about $370 \mathrm{C}$ temperature.

Currently available Waste Water Heat Recovery (WWHR) units are capable of extracting up to 17OC of heat and further preheat the incoming mains water from 10 to $270 \mathrm{C}$. Efficient results are seen when the WWHR unit is connected to thermostatically controlled shower fed with a combination of the boiler, with the preheated mains supply feeding both the shower and the boiler. Sally (2014), further confirms that the system is capable of working with a un-vented cylinder or electric shower. With respect to area of use, vertical or horizontal designs there are a number of efficient WWHR systems available in the market, however, there is a gap for a greywater recycling system integrated with WWHR unit. The most common and traditional available technology is the vertical heat exchanger. Vertical heat exchangers may suffer from the limitation of being able to install to the bathroom which is above the ground level and pressure drop of mains water in.

1) Gravity Film heat exchanger:Gravity Film Heat exchanger (GFX) is a vertical, counter flow or parallel flow heat exchanger designed to extract heat from drain warm water. Heat energy is transferred from grey warm water passing through the central large pipe to the cold fresh water moving upward through coils or without coils outside the pipe, simultaneously. Heat transfer can be improved by giving maximum contact area for the cold water with the main central pipe which is warm.

Water clings in a film like fashion to the inner wall of the pipe as it flows under gravity. The warm falling film of water around the inner wall of conducting pipe transfers heat to the cold water flowing outside it (Federal Energy Management Program, 2001). This is an immediate heat transfer scenario. All heat energy from waste water is not extracted as waste water is continuously falling through the pipe. The flow of fluid in a drainage pipe is designed to be part full and in the case of vertical pipe, greywater will flow around the inner boundary of the pipe as a film flow, on the other hand in a horizontal pipe section the water will only flow in the bottom of the pipe. High-efficiency output is achieved from vertical film flow design as the larger surface area is in contact and thus more rate of heat transfer. (McNabola 2013).
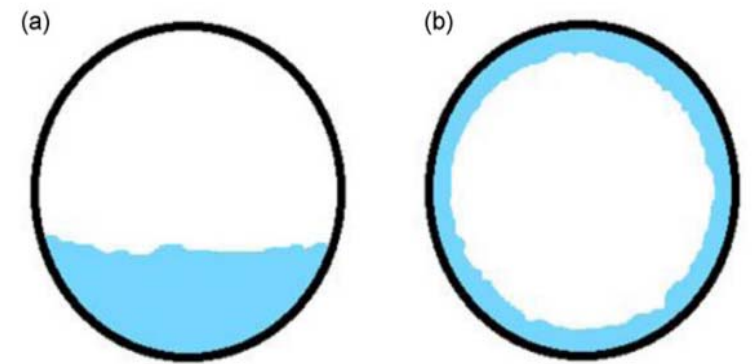

Fig 7: Typical cross-sectional view of waste water flow in (a) a horizontal drain pipe, (b) vertical drain pipe (McNabola 2013)

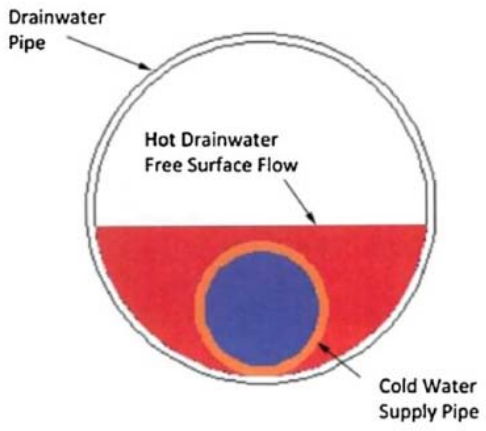

(b)

Fig8:cross section of proposed DWHR unit, horizontal plan layout of DWHR unit adaptable to fit under a bath or shower tray (McNabola 2013)

Fig 7 and 8 illustrate hot greywater in the heat recovery pipe for vertical and horizontal designsHowever, another limitation of GFX is that it would not be beneficial to preheating the water for bath, but it could be useful where there is demand for hot water for shower and production of wastewater from shower happens simultaneously. Research results shown by Federal Energy Management Program (2001), stated saving ranged from $30 \%$ to about $45 \%$ in unbalanced flow cases. 
Research conducted bySłyś andKordana, (2013) also points out that the cost effectiveness of the use of such devices increases with the number of showers taken during the day. For this reason, the greatest benefit of heat recovery from waste water discharged from the shower can be obtained in large family homes, multi-family buildings or other buildings that share a common drain from a larger number of showers.

Research which was carried out in Northern Ireland indicated the possibility of recovery of up to $75 \%$ of the heat energy contained in the waste water. It was noted, however, that in reality the operation of the device may be affected by additional factors, such as the presence of contaminants in the waste water, for example, fragments of soap, as well as air temperature inside the heat exchanger, which can result in loss of efficiency in comparison with the results obtained in the laboratory (Słyś and Kordana, 2013).

Kordana (2013), further proposes a number of WWHR design unit and tests were conducted to identify which design resulted in maximum heat recovery and most efficiency. The designs differ by the fact that preheated water is supplied only to the Boiler, only to the mixer shower, and both to the boiler and mixer shower. Fig. 9 shows the design that preheated water is used both in the Boiler (water heater) and the mixer shower.

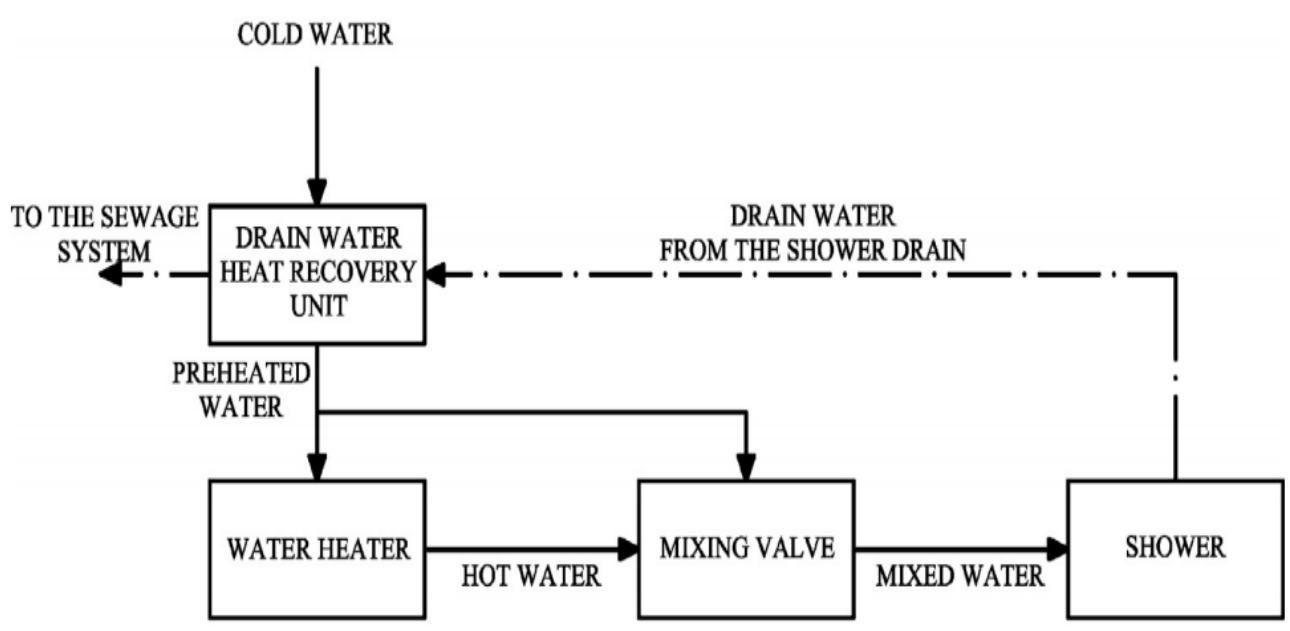

Fig 9: Preheated water supply to both Boiler and mixer shower (Słyś and Kordana, 2013).

In the study, the following basic assumptions were made (Słyś and Kordana, 2013):

1) During the flow of water through piping, heat losses do not occur.

2) Tap water during use is always the same temperature.

3) Hot water and drain water temperature are constant in time.

4) Impurities present in the drain water do not affect the efficiency of heat recovery.

The research concluded that best financial benefit is obtained from a system where preheated water is connected both to the boiler and the mixer shower. The results are acceptable as this arrangement guarantees best use of the heat recovered considering the delay in the time delay in the shower use and heat recovery operation. The financial benefits were obtained higher with an increase in the showers length and water consumption.

It was also concluded that the adopted option of the system and its performance characteristics have very significant impact on the payback period, which for the most favourable options may be about 2.5 years. However, in the case of the least favourable options, it exceeds the technical lifetime of the device.

Fig 10 illustrates a section view of implementing a vertical WWHR system in a building. There are two implementation issues with this kind of system especially for retrofitting application. One is that sometimes Boiler is far away from the bathroom, therefore connecting the preheated water to the boiler results in heat loss through pipers as well as higher installation cost (pipes travelling through rooms and hallways). The second issue is that heat recovery is lower than the bathroom and in the case of apartments, could require work on other spaces not belonging to the owner of the apartment. 


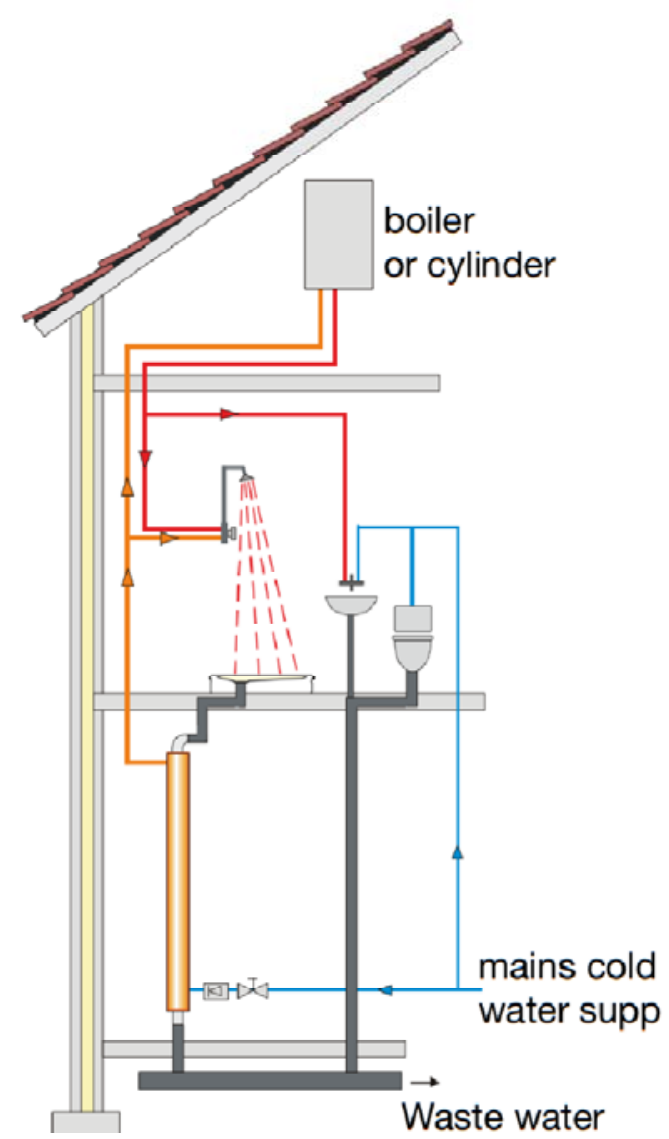

Fig 10: Design of WWHR, preheated water connected to both boiler and shower mixer in a dwelling (Shower save, 2012)

\section{ChallengeS AND OPPORTUNITIES}

Energy and water consumptions (and consequently carbon dioxide emissions) are two main pillars of the Code for Sustainable Homes which became temporary mandatory in the UK in 2008 however currently is implemented voluntary, partly due to lack of realistic technologies to achieve required sustainability levels. The code has six levels, level 6 representing a zero-carbon home and has played a significant role in improved sustainability of new-built houses in past few years. However, the property developers' focus for commercial reasons has been on achieving highest level with minimum cost and minimum negative experience by the end users. These included vastly in using efficient bulbs, appliances, fittings, taps, and high efficient heat insulations.

According to Communities and Local Government (2009), for water saving, the requirement for water consumption for various levels are as in table 8 .

TABLE 8. Max water consumption for various codes for sustainable homes

\begin{tabular}{|l|l|}
\hline Code Level & $\begin{array}{l}\text { Maximum indoor water consumption } \\
\text { in litres per person per day }\end{array}$ \\
\hline Level 1 (one star) & 120 \\
\hline Level 2 (two stars) & 120 \\
\hline Level 3 (three stars) & 105 \\
\hline Level 4 (four stars) & 105 \\
\hline Level 5 (five stars) & 80 \\
\hline Level 6 (six stars) & 80 \\
\hline
\end{tabular}

Waterwise (2009) indicates that achieving level 1-2 is possible without extra cost for new developments by using a combination of standard and efficient fittings and appliances however although level 3-4 can still be achieved by using efficient water using fittings however this could add (for level 3) up to £240 to the cost of the new home. The same reference also mentions that achieving levels 5 and 6 will require some kind of greywater recycling and could add up to $£ 4500$ to the cost of new homes. The report also indicates that greywater recycling has to be used for toilet flushing for the typical achievement of level 6 sustainable home. Waterwise 
(2009) also indicates that users are more acceptable of use of greywater recycling for toilet flushing than cloths washing however quality water saving products is important to ensure the performance of the system is acceptable to the end user.

According to above observations, greywater recycling for toilet flushing is one of most effective ways to reduce water and achieve zero carbon sustainable home levels. Challenges, however, are cost and payback period, the size of the localised greywater recycling systems making it unrealistic to be used in small bathrooms and apartments, and unfriendly user experience and ongoing costs and maintenance for the user. Another issue is that energy and water saving in most technologies have been considered separately, i.e. available commercial units are either perform greywater recycling or heat energy recovery. In rear products with the capability of greywater recycling and waste water heat recovery, the technology is not integrated to improve efficiency and/or reduce size and cost. Fig. 11 and Fig. 12 illustrate a possible diagram for integration of greywater recycling and waste water heat recovery system. Two systems could be further integrated depending on the technologies applied for a certain design.

Current waste water heat recovery units are instantaneous i.e. they recover some heat from shower water and use back to reduce energy in heating shower water. The system has a time delay to reach maximum efficiency due to the time it takes for the shower water to fully pass through the unit and some heat recovered at the end is not used. Furthermore, due to instantaneous heat recovery system, the efficiency of the units are limited especially in horizontal designs. Possible problem with vertical designs is that they could be costly to retrofit as they require changes to the main vertical sewage pipe. Finally, another shortfall of these systems is that they do not recover any heat from using bath or basins, therefore some sort of energy storage could be integrated to improve the overall efficiency of the WWHR systems.

The preheated water is used effectively in boilers and the mixer showers. The energy saving comes from requiring less energy to heat the water to a certain high temperature when feed water temperature is higher. However, this is not the case for electric showers. Most average and lower market electric showers work based on flow control rather than energy control. They comprise two heating elements and the user could manually turn one or both elements on or turn the device off. When preheated water is supplied, the water flow rate is increased so that a certain maximum temperature (usually $43 \mathrm{oC}$ ) be kept as otherwise, the output water temperature could increase to a hazardous level. Therefore, in reality, these showers not only save no energy but also increase water use in the shower when used in conjunction with a WWHR system. Considering the fact that about half of showers in the UK are electric showers (Energy Saving Trust, 2009), application of WWHR system without change to the electric showers to save energy and to be well designed to accept preheated water is required to provide an acceptable energy saving impact on WWHR use in the household.

For greywater recycling, main challenges are system size, cost and payback period, quality of water treatment and infrastructure for water storage. The commercialised technologies in this area are unlikely to fit small bathrooms in the apartments without influencing user experience. Some of the technologies in this sector require a continuous supply of material for filtration and treatment purposes and considering a minimum of $£ 1750$ retail price for these units (Waterwise, 2009), the payback period could be over 10 years depending on the household capacity. Application of new water treatment technologies and in some cases developing smaller case treatment systems for more localised that could fit small bathroom space, are opportunities in this area. However, the technologies need to be easily retrofittable which ensures the high and timely impact on water saving. An advantage of more localised greywater treatment compare to centralised large scale treatment is improved user acceptance of own greywater recycling in comparison to recycling of greywater of other users (Jeffrey, 2002) due to perceived health risks. Several past types of research show that use of greywater recycling for toilet flush has the highest public acceptance because water is not in direct contact with the users (Waterwise, n.d.). 


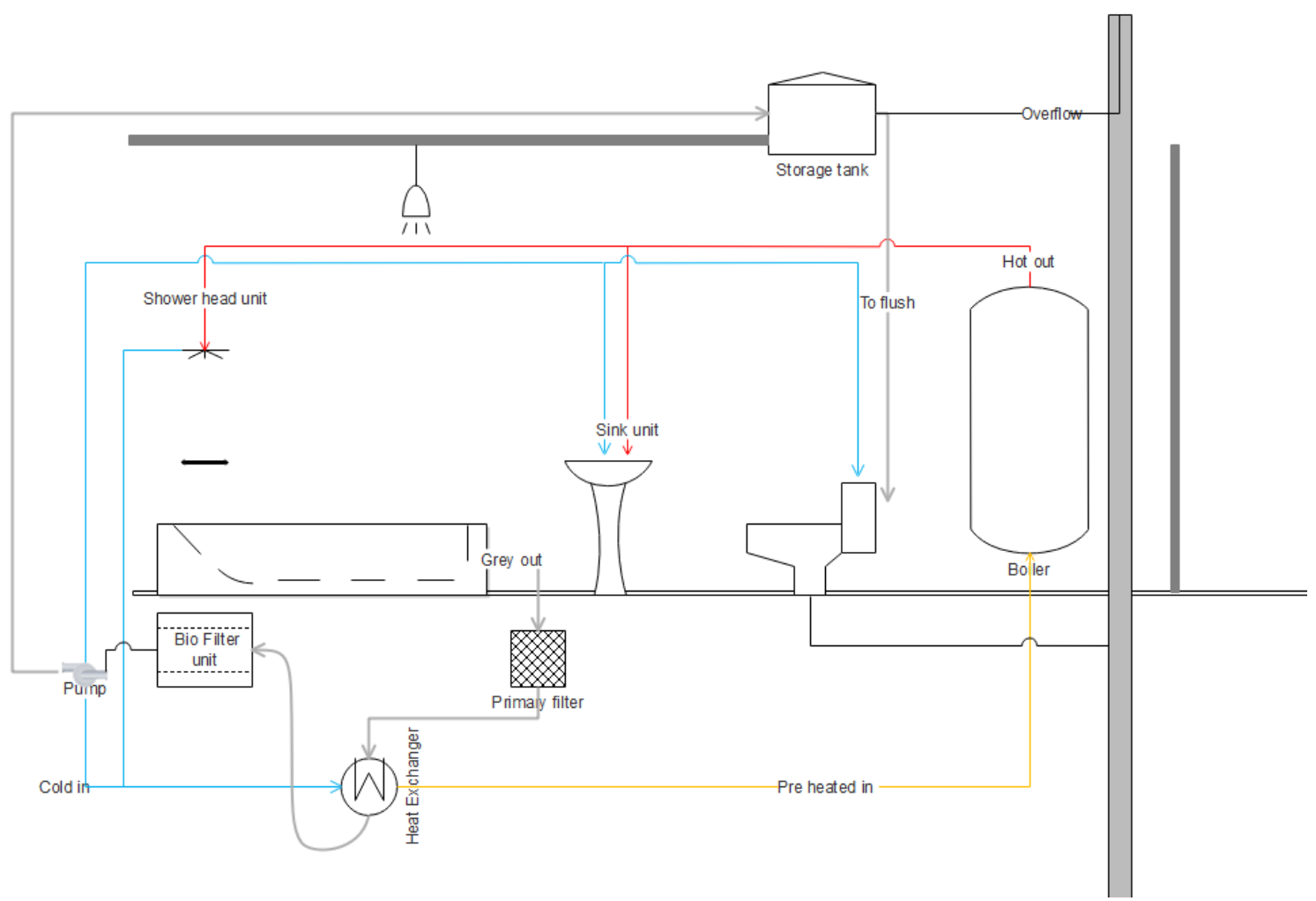

Fig 11: Schematic of combined greywater recycling for toilet flushing and heat recovery system (side view)

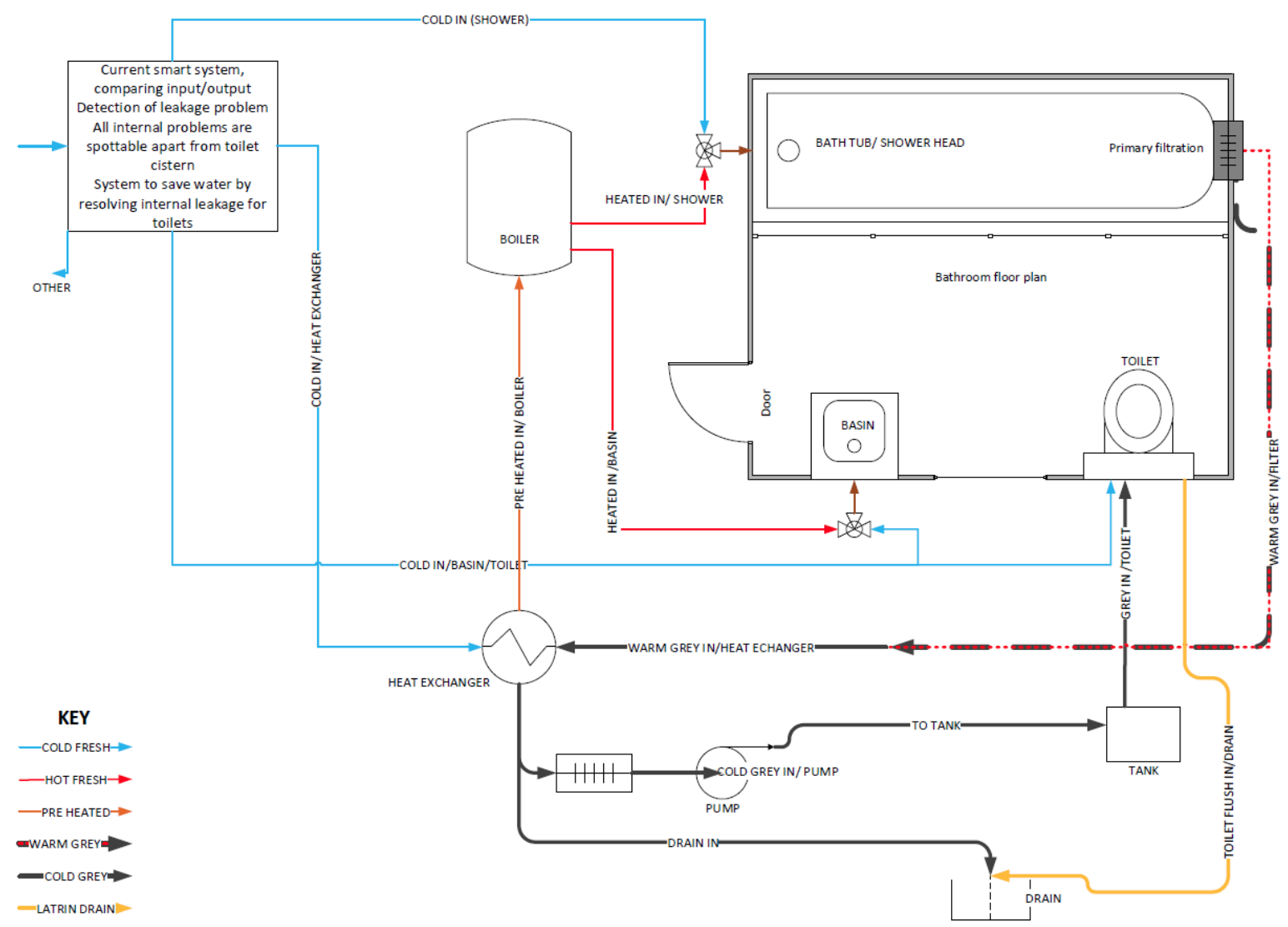

Fig 12: Schematic of combined greywater recycling for toilet flushing and heat recovery system (top view) 
Considering current stress on water treatment and supply companies and trending reduced water resources, relying only on new built technologies would only result in long term impact. Based on the fact that an average number of people per household in the UK is 2.4 (Families and Households, 2015) and considering that the UK population is approximately 65 million (Office for national statistics, 2016), there are approximately 27 million houses in the UK. With newly built target of 200000 houses per year by the UK government, it would take over hundred years to implement a new water saving technology in all households in the UK if the technology implemented in all newly built houses, therefore retrofitability is an important factor in any new technology. If one considers apartments and shared buildings, a localised integrated unit that provided choice to the public could have advantages over centralised greywater recycling or waste water heat recovery. Smart control and possible use of artificial intelligence for such localised system to adapt to the use patterns of the end users and further improve the system efficiency would be an important complement for an ideal integrated unit to save water and energy in the domestic application.Considering that most potential energy and water saving takes place in the bathroom, an integrated unit that is retrofittable only to the bathroom and does not require large renovation of the building to be installed is most likely to have highest and timely impact.

Table 2 compared different toilet systems against their initial cost, water use, performance, and drainage requirement. The adaptability of the technologies to current drain system is important in retrofitability of the toilet technologies. On the other hand, user experience and public acceptance are critical and widely varied depending on cultural, psychological, religious, gender, and other background parameters. Such example for composting toilets has been researched by Warner (n.d.). The research also finds that public acceptance further becomes more complex if toilets are for public use. Assuming an adaptable drain system to the conventional buildings and conventional user experience, and considering the fact that some water is required to wash the pan and clean water is required to fill and seal the toilet pan, Propelair technology by using 1.5 litres is one of lowest standalone toilet flushing technologies to save water however this technology to operate and look like a conventional technology requires improvements in lid operation, noise control, and size reduction for domestic applications. Integrated with other systems including the requirement for size reduction in greywater recycling, it may be that small scalable greywater recycling for toilet use can only be adapted and be commercially viable in conjunction with advances in low water, high-performance toilet flushing technologies.

Another opportunity for technology development in the bathroom is improvements in the shower and taps water delivery. Although recently many developments have taken place in reducing water flow rate from the shower without compromising user experience, however, if energy recovery and storage technologies develop, the use of preheated water in bath and basin taps becomes important for high energy efficiency of the system. This may take place simply by diverting the preheated water to the cold tap which has a disadvantage of users' inability to have cold water. The other solution could be developing mixer taps with three input, cold, preheated, and hot. The mixer will mix cold and preheated water for certain demands and if required will draw hot water from the boiler.

TABLE 9. Comparison of incentives, impact, challenges and opportunities for bathroom water and energy saving for various stakeholders

\begin{tabular}{|c|c|c|c|c|}
\hline & Incentives & Impact & Need/ Challenges & Opportunities \\
\hline $\begin{array}{l}\text { Property Owners } \\
\text { (Retrofitablemarket } \\
\text { only) }\end{array}$ & $\begin{array}{l}\text { User choice } \\
\text { Cost } \\
\text { Financial gain and } \\
\text { after payback } \\
\text { Regulations } \\
\text { Environmentally } \\
\text { friendly }\end{array}$ & $\begin{array}{l}\text { High and timely } \\
\text { energy/water saving } \\
\text { Sustainable } \\
\text { energy/water supply } \\
\text { Indirect saving as } \\
\text { result of lower } \\
\text { infrastructure } \\
\text { investment } \\
\text { requirement and } \\
\text { economic growth }\end{array}$ & $\begin{array}{l}\text { Less building } \\
\text { work, easy } \\
\text { installation } \\
\text { Size and } \\
\text { Adaptability } \\
\text { Initial and ongoing } \\
\text { cost } \\
\text { Ongoing reliability } \\
\text { and performance } \\
\text { Public Acceptance }\end{array}$ & $\begin{array}{l}\text { Possible } \\
\text { improvement in } \\
\text { bathroom } \\
\text { experience }\end{array}$ \\
\hline $\begin{array}{l}\text { Property Developers } \\
\text { (New Built market } \\
\text { Only) }\end{array}$ & $\begin{array}{l}\text { Cost } \\
\text { Regulations } \\
\text { Sustainable } \\
\text { Development } \\
\text { Code Level for } \\
\text { Sustainable Homes } \\
\text { Marketing }\end{array}$ & $\begin{array}{l}\text { Averagebut not } \\
\text { timely energy/water } \\
\text { saving } \\
\text { Business growth } \\
\text { and international } \\
\text { development }\end{array}$ & $\begin{array}{l}\text { Cost reduction } \\
\text { Integration } \\
\text { Building structure } \\
\text { considerations } \\
\text { Ongoing reliability } \\
\text { and customer } \\
\text { satisfaction }\end{array}$ & $\begin{array}{l}\text { Extendibility of } \\
\text { technologies for } \\
\text { commercial market } \\
\text { Current and future } \\
\text { regulatory } \\
\text { compliance }\end{array}$ \\
\hline Utility Companies & $\begin{array}{l}\text { Already overload } \\
\text { in some regions }\end{array}$ & $\begin{array}{l}\text { High-quality } \\
\text { service }\end{array}$ & $\begin{array}{l}\text { Technology } \\
\text { approval and }\end{array}$ & $\begin{array}{l}\text { Investment in } \\
\text { improved }\end{array}$ \\
\hline
\end{tabular}




\begin{tabular}{|c|c|c|c|c|}
\hline & $\begin{array}{l}\text { Lower operation } \\
\text { costs } \\
\text { Lower } \\
\text { Infrastructure } \\
\text { investment } \\
\text { requirement }\end{array}$ & $\begin{array}{l}\text { Sustainable } \\
\text { business model } \\
\text { Business growth }\end{array}$ & $\begin{array}{l}\text { direction } \\
\text { Mass } \\
\text { implementation } \\
\text { and public } \\
\text { marketing and } \\
\text { acceptance }\end{array}$ & operational quality \\
\hline $\begin{array}{l}\text { Technology } \\
\text { Developing } \\
\text { Companies }\end{array}$ & $\begin{array}{l}\text { Research, } \\
\text { development and } \\
\text { Intellectual } \\
\text { Property } \\
\text { Rapid business } \\
\text { growth } \\
\text { Transferrable } \\
\text { technologies for } \\
\text { other markets }\end{array}$ & $\begin{array}{l}\text { Increase business } \\
\text { value } \\
\text { Domestic and } \\
\text { international growth }\end{array}$ & $\begin{array}{l}\text { Research and } \\
\text { development and } \\
\text { value engineering } \\
\text { Initial } \\
\text { development } \\
\text { investment } \\
\text { Marketing and } \\
\text { communicating } \\
\text { with other } \\
\text { stakeholders }\end{array}$ & $\begin{array}{l}\text { Scaled down or up } \\
\text { technologies } \\
\text { High market and } \\
\text { rapid growth } \\
\text { Extendibility of } \\
\text { technologies for } \\
\text { other markets } \\
\text { including } \\
\text { commercial } \\
\text { buildings }\end{array}$ \\
\hline Government & $\begin{array}{l}\text { Achieving and } \\
\text { setting realistic } \\
\text { environmental } \\
\text { targets } \\
\text { Lower } \\
\text { infrastructure } \\
\text { investment } \\
\text { Economic growth } \\
\text { Technology export } \\
\text { and trade balance }\end{array}$ & $\begin{array}{l}\text { More investment } \\
\text { for growth rather } \\
\text { than infrastructure } \\
\text { Lower need for tax } \\
\text { and income } \\
\text { increase }\end{array}$ & $\begin{array}{l}\text { Right and timely } \\
\text { regulatory and } \\
\text { legislative } \\
\text { incentives } \\
\text { Research and } \\
\text { development } \\
\text { support }\end{array}$ & $\begin{array}{l}\text { Compliance with } \\
\text { international } \\
\text { environmental } \\
\text { agreements } \\
\text { Economic growth } \\
\text { and reduce financial } \\
\text { deficit }\end{array}$ \\
\hline
\end{tabular}

TABLE 9. Challenges and opportunities for Individual components and technologies and integrated and holistic approach to bathroom water and energy saving

\begin{tabular}{|c|c|}
\hline & Challenges/Opportunities \\
\hline $\begin{array}{l}\text { Greywater } \\
\text { Recycling }\end{array}$ & $\begin{array}{l}\text { - Technology scale down } \\
\text { - Technology reliability and performance over time } \\
\text { - Technology initial and ongoing costs and reasonable payback time } \\
\text { - Marketing and public/stakeholder acceptance } \\
\text { - } \quad \text { Required investment }\end{array}$ \\
\hline $\begin{array}{l}\text { Waste Water } \\
\text { Heat Recovery }\end{array}$ & $\begin{array}{l}\text { - } \quad \text { Higher efficiency } \\
\text { - } \quad \text { Energy storage } \\
\text { - } \quad \text { Energy saving products using preheated water } \\
\text { - } \quad \text { Long term reliability and performance consistency } \\
\text { - Marketing and public/stakeholder acceptance } \\
\end{array}$ \\
\hline Toilet & $\begin{array}{l}\text { - } \quad \text { Performance decline in low water toilets } \\
\text { - } \quad \text { Limited in potable water saving } \\
\text { - } \quad \text { Initial cost of new technologies } \\
\text { - Sewage compatibility of new technologies } \\
\text { - } \quad \text { Public acceptance of new technologies } \\
\end{array}$ \\
\hline Shower & $\begin{array}{l}\text { - Energy saving when preheated water supplied in electric showers } \\
\text { - Reducing water volume to user experience ratio } \\
\text { - Value engineering in effective mixing technologies } \\
\text { - } \quad \text { Phase start and stop for effective operation }\end{array}$ \\
\hline $\begin{array}{l}\text { Basin/Bath } \\
\text { Taps }\end{array}$ & $\begin{array}{l}\text { - } \quad \text { Preheated water input for energy saving } \\
\text { - } \quad \text { Reducing water volume to user experience ratio } \\
\text { - } \quad \text { Value engineering in effective mixing technologies } \\
\end{array}$ \\
\hline Integrated Unit & $\begin{array}{l}\text { - All above plus } \\
\text { - Integration and therefore related innovation challenges and opportunities for } \\
\text { more efficiency }\end{array}$ \\
\hline
\end{tabular}




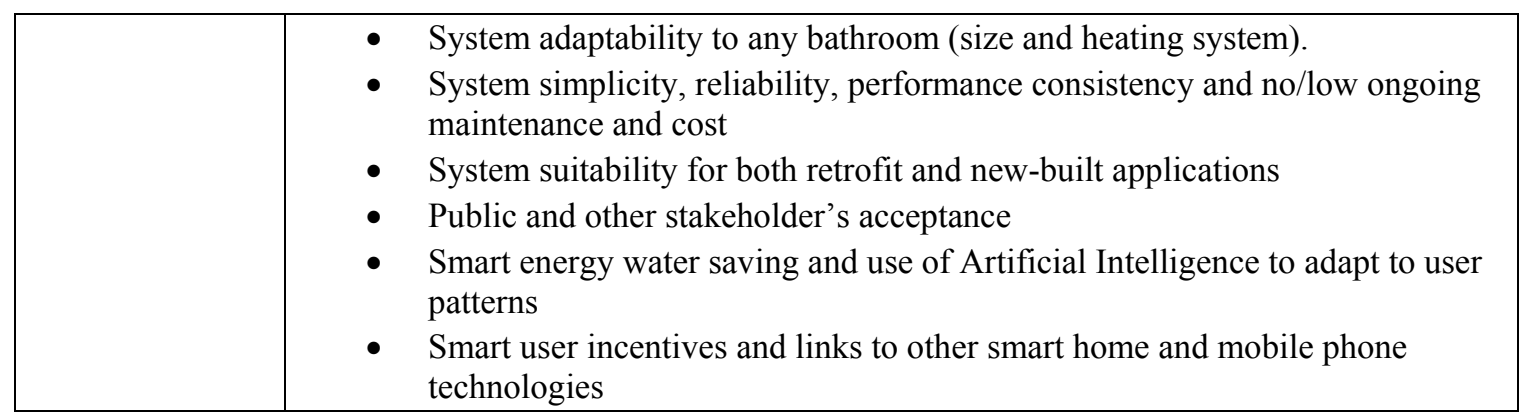

Table 9 shows incentives, impact, challenges and opportunities for energy/water saving in the bathroom. The table looks at the property owner as a retrofit market and property developer as the new-built market, however, these two could overlap if technology could be applied for both retrofit and new-built home market. The table illustratesthe large positive impact of such technologies from point of all stakeholders however payback as the results of initial and ongoing cost as well as public acceptance pay major role for mass technology adoption and high and timely impact.

Table 10 lists the challenges and opportunities related to an individual component in the bathroom and integrated energy/water saving technology. It is clear from the table for both energy and water, the idea of effective extracting/collecting, storing/treating, and reusing depends interaction between all the components in the bathroom and a single technology although would have some benefits however its efficiency is limited to the scope of operation and other components in the bathroom. The idea of integrated water and energy saving looks inevitable for targeting future zero carbon and sustainable homes and to have a timely impact on the decline of resources, overloading of infrastructure, and required large investments required in the utility sector.

\section{CONCLUSION}

This research reviewed a range of articles related to the need for energy and water saving in the bathroom. Various technologies including for water saving in domestic buildings were analysed. These were classified as indirect methods such as rain water harvesting and greywater recycling and direct methods by improvements to fittings, toilet flushing technology and so on.

The research reviewed also various methods for waste water heat recovery technologies and especially looked at horizontal and vertical designs. Due to the time delay of instantaneous operation of these technologies, some inefficiencies occur. Furthermore, these technologies are completely ineffective in the case of using bath and therefore improvements could take place by an energy storage and reuse technology.

The research investigates incentives, impact, challenges, and opportunities for various stakeholders, home owners, property developers, utility companies, technology companies and the government. There are many incentives for different stakeholders making this area an opportunity for technology developers and businesses however innovations need to apply to reduce the size and payback period and to be able to develop products that can be retrofitted to current homes.

After comparison of different challenges for individual components, the conclusion was that an integrated approach not only could improve the water and energy efficiency but also can reduce cost and size compare to improvements to sum of individual components in the bathroom, therefore the payback period could highly reduce providing major incentive to the current property owners and developers to adapt an integrated unit. Such system will be easily smartly controlled to take into account the use patterns and adapt for optimum water and energy saving efficiency.

\section{REFERENCES}

[1] Albalawneh, A. and Chang, T. (2015). REVIEW OF THE GREYWATER AND PROPOSED GREYWATER RECYCLING SCHEME FOR AGRICULTURAL IRRIGATION REUSES. International Journal of Research -GRANTHAALAYAH, [online] 3(12), p.16. Available at: http://granthaalayah.com/Articles/Vol3Iss12/03_IJRG15_C12_71.pdf [Accessed 21 February 2018].

[2] Allen, Lucy, Juliet Christian-Smith, and MeenaPalaniappan. Overview Of Greywater Reuse: The Potential Of Greywater Systems To Aid Sustainable Water Management. 1st ed. California: Pacific Institute, 2010. Web. 26 Jan. 2017.

[3] Association for Rainwater Harvesting and Water Utilisation, (n.d.). Greywater Recycling and Reuse. [online] pp.1-8. Available at: http://www.fbr.de/fileadmin/user_upload/files/Englische_Seite/Greywater_Recycling_Introduction.pdf [Accessed February 2018].

[4] Boyjoo, Y., Pareek, V. and Ang, M. (2013). A review of greywater characteristics and treatment processes. Water Science \& Technology, 67(7), p.1403.

[5] Bull, J. (2011). The carbon footprint of tap water - oCoCarbon. [online] oCoCarbon. Available at: http://oco-carbon.com/metrics/thecarbon-footprint-of-tap-water/ [Accessed February 2018].

[6] Center for the Study of the Built Environment (CSBE). (2003). Graywater Reuse in Other Countries and its Applicability to Jordan.

[7] Chaillou, K., Gérente, C., Andrès, Y., Wolbert, D., 2011. Bathroom greywater characterization and potential treatments for reuse. Water, Air, \& Soil Pollution 215, 31- 42.

[8] Communities and Local Government (2009). The Water Efficiency Calculator for new dwellings. [online] communities.gov.uk. Available at: http://www.planningportal.gov.uk/uploads/br/water_efficiency_calculator.pdf [Accessed February 2018]. 
[9] Defra (2008), Future Water: The Government's water strategy for England. Available at: https://www.gov.uk/government/uploads/system/uploads/attachment_data/file/69346/pb13562-future-water-080204.pdf. [Accessed February 2018].

[10] Department for Communities and Local Government, BREEAM Centre at the Building Research Establishment (BRE) (2010). Code for Sustainable Homes- Technical Guide (November 2010). Available at: https://www.gov.uk/government/uploads/system/uploads/attachment_data/file/5976/code_for_sustainable_homes_techguide.pdf. [Accessed 01 February 2018].

[11] Department of Energy and Climate Change (2012). The Energy Efficiency Strategy: The Energy Efficiency Opportunity in the UK. Available at: https://www.gov.uk/government/uploads/system/uploads/attachment_data/file/65602/6927-energy-efficiency-strategy-the-energy-efficiency.pdf. [Accessed 01 February 2018].

[12] Department of Energy and Climate Change (2014). UK National Energy Efficiency Action Plan. Available at: https://ec.europa.eu/energy/sites/ener/files/documents/2014_neeap_united-kingdom.pdf. [Accessed 01 February 2018].

[13] Energy Saving Trust (2009). The water and energy implications of bathing and showering behaviours and technologies. [online] Available at: http://www.waterwise.org.uk/resources.php/27/the-water-and-energy-implications-of-bathing-and-showering-behavioursand-technologies [Accessed 17 February 2018].

[14] Energy Saving Trust, (2013). at home with water. 1st ed. [ebook] London: Energy Saving Trust, pp.16,14,32. Available at: http://www.energysavingtrust.org.uk/sites/default/files/reports/AtHomewithWater(7).pdf [Accessed 20February 2018].

[15] Environment Agency (2007). Conserving water in buildings - A practical guide. Available at: $\mathrm{http}: / / w w w . e l e m e n t a l s o l u t i o n s . c o . u k / w p-c o n t e n t / u p l o a d s / 2012 / 08 /$ conserving-water-in-buildings.pdf. [Accessed 01 February 2018].

[16] Environment Agency (2013). Areas of water stress: final classification, Reference number/code GEHO1207BNOC-E-E. Available at: http://webarchive.nationalarchives.gov.uk/20140328104527/http://cdn.environment-agency.gov.uk/LIT_8538_535424.pdf [Accessed 01 February 2018]

[17] Environment Agency, (2011). Greywater for domestic users: an information guide. [online] Bristol: Environment Agency, pp.12-15. Available http://www.sswm.info/sites/default/files/reference attachments/ENVIRONMENT\%20AGENCY\%202011\%20Greywater\%20for\%20 Domestic\%20Users.pdf [Accessed 27 February 2018].

[18] Environmental Protection Agency, (2013). Water saving technologies to reduce water consumption and wastewater production in Irish households., STRIVE programme. STRIVE Report Series No. 108. Available at: https://www.epa.ie/pubs/reports/research/water/STRIVE_108_Water\%20saving\%20technologies....pdf.

[19] Envirowise, (2008). REDUCING WATER USE IN WASHROOMS: WCs. ENVIROWISE WATER MANAGEMENT LEAFLET. [online] Oxfordshire: AEA Technology plc and Serco TT, p.2. Available at: http://www.wrap.org.uk/sites/files/wrap/EN667R_v2_Feb_9_2009.pdf [Accessed 20February 2018].

[20] Families and Households (2015). Families and Households: 2015. [online] Available at: https://www.ons.gov.uk/peoplepopulationandcommunity/birthsdeathsandmarriages/families/bulletins/familiesandhouseholds/2015-1105 [Accessed 17 February 2018].

[21] Ferguson, D. (2016). Greywater systems: can they really reduce your bills? [online] the Guardian. Available at: https://www.theguardian.com/lifeandstyle/2014/jul/21/greywater-systems-can-they-really-reduce-your-bills [Accessed 21 February 2018].

[22] Fewkes, A. (2005). The technology, design and utility of rainwater catchment systems. In Water Demand Management., Memon, FA and Butler, D (eds). IWA Publishing.

[23] Friedler, E, and M Hadari. Economic Feasibility Of On-Site Greywater Reuse In Multi-Storey Buildings. 1st ed. Israel: Division of Environmental, Water and Agricultural Engineering, Faculty of Civil and Environmental Engineering, 2006. Web. 2 May 2017.

[24] Friedler, E., Hadari, M., 2006. Economic feasibility of on-site greywater reuse in multistorey buildings. Desalination 190, 221-234. [23] Friedler, E., Kovalio, R., Ben-Zvi, A., 2006. Comparative study of the microbial quality of greywater treated by three on-site treatment systems. Environmental technology 27, 653-663. or

[25] Ghaitidak, D.M., Yadav, K.D., 2013. Characteristics and treatment of greywater-A review. Environmental Science and Pollution Research 20, 2795-2809.

[26] Grant, N. and Moodie, M. (1999). 1st ed. [ebook] Leeds: Elemental Solutions, p.1. Available at: http://www.solutionelements.co.uk/Downloads\%20copy/WCstate\%20of\%20the\%20art.pdf [Accessed 17 February 2018].

[27] Home-water-works.org. (2017). Toilets | Home Water Works. [online] Available at: http://www.home-water-works.org/indooruse/toilets [Accessed 17 February 2018].

[28] Jeffrey, P. (2002). Public attitudes to in-house water recycling in England and Walse. Journal of the Chartered Institution of Water and Environmental Management, Vol. 16, pp. 214-217.

[29] Johnson, A. and Burton, J. (2017). Water torture: 3,300,000,000 litres are lost every single day through. [online] The Independent. Available at: http://www.independent.co.uk/news/uk/home-news/water-torture-3300000000-litres-are-lost-every-single-day-throughleakage-2034999.html [Accessed 12 February 2018].

[30] Li, F., Wichmann, K. and Otterpohl, R. (2009). Review of the technological approaches for greywater treatment and reuses. Science of The Total Environment, 407(11), pp.3439-3449.

[31] Li, F., Wichmann, K., Otterpohl, R., 2009. Review of the technological approaches for greywater treatment and reuses. Science of the Total Environment 407, 3439-3449.

[32] Lin, C.-J., Lo, S.-L., Kuo, C.-Y., Wu, C.-H., 2005. Pilot-scale electrocoagulation with bipolar aluminum electrodes for on-site domestic greywater reuse. Journal of environmental engineering 131, 491-495

[33] Lowenergyhouse.com. (2017). Low Energy House - Greywater Systems - Water Collection. [online] Available at: http://www.lowenergyhouse.com/grey-water-systems.html [Accessed 20February 2018].

[34] Markham, D. (2014). Next-generation heat exchanger recovers heat from shower drains to preheat water. [online] TreeHugger. Available at: http://www.treehugger.com/clean-technology/next-generation-heat-exchanger-captures-waste-heat-drain-shower.html [Accessed 20 Jan. 2018].

[35] Morel, A. and Diener, S. (2006). Greywater management in low an [i.e. and] middle-income countries. 1st ed. Dübendorf: Sandec at Eawag.

[36] Nolde, E., 2000. Greywater reuse systems for toilet flushing in multi-storey buildings- over ten years' experience in Berlin. Urban water 1, 275-284

[37] NSW Department of water and Energy, (2008). GREYWATER REUSE IN SEWERED, SINGLE HOUSEHOLD RESIDENTIAL PREMISES. [online] Sydney: Department of Energy, Utilities and Sustainability, pp.12-14. Available at: http://www.water.nsw.gov.au/_data/assets/pdf_file/0008/557324/recycling_grey_nsw_guidelines_for_greywater_reuse_in_sewered_s ingle_household_residential_premises.pdf [Accessed 27 Jan. 2018]. 
[38] Office for National Statistics (2016). Population estimates for UK, England, Wales, Scotland and Northern Ireland: mid 2016. [online] Available https://www.ons.gov.uk/peoplepopulationandcommunity/populationandmigration/populationestimates/bulletins/annualmidyearpopulat ionestimates/latest [Accessed 17 July 2018].

[39] Ofwat (2015). Affordability and debt 2014-15- supporting information. Available at: http://www.ofwat.gov.uk/wpcontent/uploads/2015/12/pap_tec20151201affordabilitysupp.pdf. [Accessed 01 February 2018].

[40] Palmer, J. and Cooper, I. (2013). United Kingdom housing energy fact file, Department of Energy \& Climate Change (2013). Available at: https://www.gov.uk/government/uploads/system/uploads/attachment_data/file/345141/uk_housing_fact_file_2013.pdf. [Accessed 01 February 2018].

[41] Parkes, C., Kershaw, H., Hart, J., Sibille, R. and Grant, Z. (2011). Energy and carbon implications of rainwater harvesting and greywater recycling. 1st ed. Bristol: Environment Agency.

[42] Pidou, M. et al. "Greywater Recycling: Treatment Options And Applications". Proceedings of the Institution of Civil Engineers Engineering Sustainability 160.3 (2007): 119-131. Web. 2 May 2017.

[43] Pidou, M., Memon, F.A., Stephenson, T., Jefferson, B., Jeffrey, P., 2007. Greywater recycling: treatment options and applications. Proceedings of the ICE-Engineering Sustainability 160, 119-131 or

[44] Propelair®. (2017). Propelair® | The Toilet Reinvented. [online] Available at: http://www.propelair.com [Accessed 27 Jan. 2018].

[45] Queensland, G. (2002). Guidelines for the use and disposal of greywater in unsewered areas, N.R.a.M. Queensland Government, ed, pp. 10.

[46] R, R. (2016). Supports and Connections I SkyCiv Cloud Engineering Software. [online] Skyciv.com. Available at: https://skyciv.com/education/types-of-supports-in-structural-analysis/ [Accessed 16 February 2018].

[47] Shreeve, P., Ward, S. and Butler, D. (2013). Innovations in Residential Rainwater Harvesting in the UK.

[48] Słys', D. and Kordana, S. (2014). Financial analysis of the implementation of a Drain Water Heat Recovery unit in residential housing. Energy and Buildings 71, 1-11. Available at: http://ac.els-cdn.com/S0378778813008062/1-s2.0-S0378778813008062main.pdf?_tid=63efd27c-76cb-11e7-abe5-00000aab0f02\&acdnat=1501600339_ce2850470a22dd5690e3440deea1 f409. [Accessed 01 February 2018].

[49] southwestwater.co.uk, (2016). Understanding your water usage. 1st ed. [ebook] southwest water, p.10. Available at: https://www.southwestwater.co.uk/media/pdf/k/t/UVUv6_0716_Web_version.pdf [Accessed 17 February 2018].

[50] The Water Label (2017). Setting the European standard for water-efficient products. [online] Europeanwaterlabel.eu. Available at: http://www.europeanwaterlabel.eu/map.asp\#GB [Accessed 17 February 2018].

[51] UK government (2011).

https://www gov.uk/government/uploads/system/uploads/attachment_data/file/47621/1358-th February 2018].

[52] United Nations (2014). Water and Energy Sustainability Information brief. Available at: http://www.un.org/waterforlifedecade/pdf/01_2014_sustainability_eng.pdf. [Accessed 01 February 2018].

[53] User, Super. "Recoh-Vert - Shower Save". Shower-save.com. N.p., 2017. Web. 2 May 2017.

[54] Ward, S. (2013). Rainwater Harvesting in the UK - Current Practice and Future Trends. [online] Harvesth2o.com. Available at: http://www.harvesth2o.com/rainwater_harvesting_UK.shtml [Accessed 27 Jan. 2018].

[55] Warner S. William (n.d). Cultural Influences that Affect the Acceptance of Compost Toilets: Psychology, Religion and Gender. [online] Available at: https://www.researchgate.net/publication/260388107_Cultural_Influences_that_Affect_the_Acceptance_of_Compost_Toilets_Psychol ogy_Religion_and_Gender [Accessed 17 February 2018].

[56] Waterwise (2009). Water efficiency in new developments: a best practice guide. [online] Available at: http://www.waterwise.org.uk/data/resources/28/Water-efficiency-in-new-developments_A-best-practice-guide.pdf [Accessed 17 February 2018].

[57] Waterwise (n.d.). Available at: http://www.waterwise.org.uk/pages/why-we-need-to-save-water.html. [Accessed 01 February 2018].

[58] Waterwise (n.d.). Perceptions of rainwater \& greywater. [online] Available at: http://www.waterwise.org.uk/pages/perceptions-ofrainwater-greywater.html [Accessed 17 February 2018].

[59] World Health Organization, (2006). Overview of greywater management Health considerations. Discussed and approved at the regional consultation on national priorities and plans of action on management and reuse of wastewater. [online] Amman: World Health Organization, pp.7-12. Available at: http://applications.emro.who.int/dsaf/dsa1203.pdf [Accessed 27 Jan. 2018]. 